Original article

\title{
2-Pyridyl thiazoles as novel anti-Trypanosoma cruzi agents: Structural design, synthesis and pharmacological evaluation
}

\author{
Marcos Veríssimo de Oliveira Cardoso ${ }^{a}$, , Lucianna Rabelo Pessoa de Siqueira ${ }^{a}$, \\ Elany Barbosa da Silva a , Lívia Bandeira Costa ${ }^{a}$, Marcelo Zaldini Hernandes a , \\ Marcelo Montenegro Rabello a, Rafaela Salgado Ferreira ${ }^{\text {b }}$, Luana Faria da Cruz ${ }^{\text {b }}$, \\ Diogo Rodrigo Magalhães Moreira ${ }^{c}$, Valéria Rêgo Alves Pereira ${ }^{\mathrm{d}}$, \\ Maria Carolina Accioly Brelaz de Castro ${ }^{d}$, Paul V. Bernhardt ${ }^{e}$, Ana Cristina Lima Leite ${ }^{a}$ \\ a Departamento de Ciências Farmacêuticas, Centro de Ciências da Saúde, Universidade Federal de Pernambuco, 50740-520 Recife, PE, Brazil \\ b Departamento de Bioquímica e Imunologia, Universidade Federal de Minas Gerais, CEP 31270-901 Belo Horizonte, MG, Brazil \\ ${ }^{c}$ Centro de Pesquisas Gonçalo Moniz, Fundação Oswaldo Cruz, CEP, 40296-750 Salvador, BA, Brazil \\ d Centro de Pesquisas Aggeu Magalhães, Fundação Oswaldo Cruz, CEP, 50670-420 Recife, PE, Brazil \\ e School of Chemistry and Molecular Biosciences, University of Queensland, Brisbane 4072, Australia
}

\section{A R T I C L E I N F O}

\section{Article history:}

Received 17 April 2014

Received in revised form

1 August 2014

Accepted 5 August 2014

Available online 6 August 2014

\section{Keywords:}

Chagas disease

Trypanosoma cruzi

Thiazoles

Hydrazones

2-Pyridine thiosemicarbazone

\begin{abstract}
A B S T R A C T
The present work reports on the synthesis, anti-Trypanosoma cruzi activities and docking studies of a novel series of 2-(pyridin-2-yl)-1,3-thiazoles derived from 2-pyridine thiosemicarbazone. The majority of these compounds are potent cruzain inhibitors and showed excellent inhibition on the trypomastigote form of the parasite, and the resulting structure-activity relationships are discussed. Together, these data present a novel series of thiazolyl hydrazones with potential effects against Chagas disease and they could be important leads in continuing development against Chagas disease.
\end{abstract}

๑) 2014 Elsevier Masson SAS. All rights reserved.

\section{Introduction}

Chagas disease, also known as American trypanosomiasis, is a potentially life-threatening illness caused by the protozoan parasite Trypanosoma cruzi (T. cruzi) [1]. About 7-8 million people worldwide are estimated to be infected with $T$. cruzi, mainly in Latin America.

Over the years, numerous chemical classes against $T$. cruzi have become available, but there is still no effective treatment for all phases of the disease [2]. Recent research has pointed to the ergosterol biosynthetic pathway as a biochemical target [3,4]. Azole derivatives such as posaconazole and ravuconazole, have been tested and presented trypanocidal activity, but they are not yet available as therapeutics [5-7].

Despite the efforts of many investigators in the research of a new anti-Chagas drugs, only two drugs are currently used to treat

\footnotetext{
* Corresponding author.

E-mail address: marcosvocardoso@gmail.com (M.V.O. Cardoso).
}

it, nifurtimox and benznidazole [6,8] (Fig. 1). Current chemotherapy for Chagas disease is unsatisfactory due to its limited efficacy, particularly in the chronic phase, with frequent side effects that can lead to discontinuation of treatment.

Among a number of drug targets being investigated for Chagas disease, cruzain, the major cysteine protease active in the parasite, is a prominent candidate [9-12]. Cruzain is a cathepsin-L-like protease of the papain family thought to be important for intracellular replication and differentiation of the $T$. cruzi parasite [13]. Among the chemical groups explored for anti-Chagas activity, thiazolyl hydrazones are noteworthy because of their wide biological, especially anti-parasitic, activities [14-17].

In 2004, Greenbaum et al. observed that thiosemicarbazones with a pyridyl moiety inhibit cruzain catalytic activity [18]. Subsequent studies have demonstrated the trypanocidal activity of thiosemicarbazones and their metal complexes. Recently, Caputo et al. have demonstrated trypanocidal activity for a series of 4arylthiazolylhydrazones [19], with a broad and potent activity for all forms of the parasite. Recently studies have reported inhibition 
<smiles>CC1CS(=O)(=O)CCN1/N=C/c1ccc([N+](=O)[O-])o1</smiles>

Nifurtimox<smiles>O=C(Cn1ccnc1[N+](=O)[O-])NCc1ccccc1</smiles>

Benznidazole
Fig. 1. Structures of nifurtimox and benznidazole.

of the cysteine protease cruzain by thiosemicarbazones [16]. Our efforts toward new antichagasic drug since 2010 have led us to a variety of thiosemicarbazones and thiazolyl hydrazones as trypanocidal agents [16,19-22]. The promising results achieved by compounds bearing a thiazole ring motivated us to investigate the trypanocidal activity of novel thiazolyl hydrazones derived from 2pyridyl thiosemicarbazone, with changes being made in the phenyl ring attached in N2. In continuation of our search for bioactive molecules, we envisaged that the derivatization of the thiosemicarbazone group into thiazole moiety would generate novel templates, which are likely to exhibit anti-T. cruzi activity. We also investigate pyridines as trypanocidal agents because their wide applicability in organic synthesis, low price and facility in synthesis. Here, these compounds were tested in vitro against $T$. cruzi parasite epimastigote and trypomastigote forms, and cruzain protease. In this synthetic design of a structure-activity relationship (SAR) library, attention was paid to further explore substituents around the phenyl ring attached in thiazole ring (C9). This study generated basic SARs about tripomastigote form and cruzain enzyme around substituents in phenyl ring, and using the scaffold shown in Scheme 1. Specifically, we report the preparation of twenty-four 2(pyridin-2-yl)-1,3-thiazoles (3-27) by ultrasound-assisted synthesis. The synthesized compounds were characterized by IR, NMR and mass spectral studies. The 2-(pyridin-2-yl)-1,3-thiazoles were assayed for their in vitro anti-T. cruzi activity against the epimastigote and trypomastigote forms of the parasite. Their cytotoxicity in mammalian cell cultures was also investigated. Further investigations on the possible involvement of 2-(pyridin-2-yl)-1,3thiazoles with cruzain activity as potential therapeutic targets were performed.

\section{Results and discussion}

\subsection{Chemistry}

2-(pyridin-2-yl)thiosemicarbazones (2a-b) were prepared by reacting commercially available thiosemicarbazides with the appropriate aldehyde or ketone (1:1.2 mol ratio) via Schiff base condensations using ultrasound irradiation in presence of a catalytic amount of $\mathrm{AcOH}$. This reaction condition led to high yields (80-90\%). 2-(pyridin-2-yl)-1,3-thiazoles (3-26) were prepared via Hantsch cyclization between 2-(pyridin-2-yl)thiosemicarbazones (2a-b) and substituted 2-bromoacetophenones (Scheme 1). These reactions proceed well upon refluxing with ethanol $(2-4 \mathrm{~h})$, but here we adapted this to ultrasound conditions at room temperature [23] using 2-propanol as solvent [24]. This resulted in good yields (50-85\%) and shorter reaction times (60 min in most cases) compared with the reflux protocol.

Microanalysis and NMR data are compatible with the proposed compounds. In theory, two geometrical isomers ( $E$ and $Z$ ) about the imine $(\mathrm{C}=\mathrm{N})$ double bond are possible for the thiosemicarbazones. However, analysis of the ${ }^{1} \mathrm{H}$ NMR spectra of the target compound indicated one predominant isomer; the $E$ isomer by comparison with known analogues [25]. Intramolecular H-bonding involving the proton attached to N4 (in DMSO) with the imine N-atom leads to a distinctive singlet around $10.2 \mathrm{ppm}$ [25] and this is also seen here.

Once thiosemicarbazones were characterized, the respective 2(pyridin-2-yl)-1,3-thiazoles were characterized by usual spectroscopy. As exemplified with the ${ }^{1} \mathrm{H}$ NMR analysis of (2-(1-(pyridin-2yl)ethylene)hydrazinyl)-4-phenyl-1,3-thiazole (15), the singlet peak at $\delta 2.43$ corresponds to the methyl group. The aromatic protons occurred as doublets or triplets. For the pyridyl ring, peaks were observed at $\delta 7.76,8.23,8.35$ and 8.73 . For the aromatic ring coupled to the thiazole ring, doublet and triplet peaks were found at $\delta 7.30,7.39$ and 7.85. For the thiazole ring, a singlet at $\delta 7.44$ was found. In addition, the $\mathrm{NH}$ proton appeared as broad singlet at $\delta$ 5.53. The ${ }^{13} \mathrm{C}$ NMR spectrum of $(\mathbf{1 5})$ the ${ }^{13} \mathrm{C}=\mathrm{S}$ resonance from the parent thiosemicarbazone disappeared while a new ${ }^{13} \mathrm{C}-\mathrm{H}$ resonance at $\sim 106 \mathrm{ppm}$ appeared, confirming cyclization in addition to the resonance at $169 \mathrm{ppm}$. Quaternary carbon peaks were confirmed by DEPT experiments to appear at $\delta 134.2,140.1,150.0$ and 168.9. Peaks of the pyridine aromatic carbons were found at

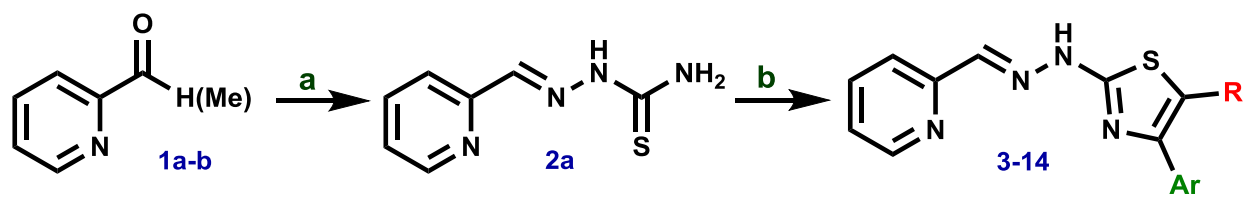

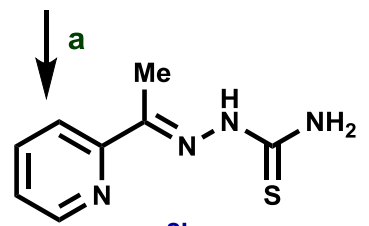

$2 b$<smiles>[R]c1sc(N/N=C(\C)c2ccccn2)nc1Br</smiles>

\begin{tabular}{|c|c|c|c|}
\hline \multicolumn{2}{|c|}{; Compd. , Ar } & \multicolumn{2}{|c|}{ Compd.' Ar } \\
\hline 3 & $\mathrm{Ph}$ & 15 & :Ph \\
\hline 4 & :4- $\mathrm{CH}_{3}-\mathrm{Ph}$ & 16 & ; $4-\mathrm{CH}_{3}-\mathrm{Ph}$ \\
\hline 5 & :4-Br-Ph & 17 & :4-Br-Ph \\
\hline & 4-Br-Ph(R:Me) & 18 & 4-Br-Ph(R:Me \\
\hline 7 & 4-F-Ph & 19 & 4-F-Ph \\
\hline ; & ;4-MeO-Ph & 20 & :4-MeO-Ph \\
\hline ;9 & 4-Cl-Ph & 21 & 4-Cl-Ph \\
\hline 10 & 2,4-diCl-Ph & 22 & 2,4-diCl-Ph \\
\hline :11 & :3,4-diCl-Ph & 23 & $3,4-d i \mathrm{Cl}-\mathrm{Ph}$ \\
\hline 12 & ; $3-\mathrm{NO}_{2}-\mathrm{Ph}$ & 24 & $3-\mathrm{NO}_{2}-\mathrm{Ph}$ \\
\hline 13 & $: 4-\mathrm{NO}_{2}-\mathrm{Ph}$ & 25 & $4-\mathrm{NO}_{2}-\mathrm{Ph}$ \\
\hline & :2-Naphthyl & 26 & 2-Naphth \\
\hline
\end{tabular}

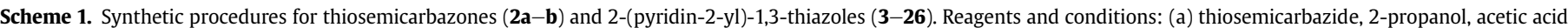

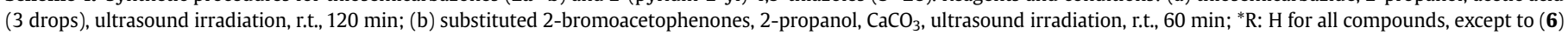
and (18) where R: Me. 
$\delta 123.6,125.6,143.9,147.5$, and 150.0. Resonances from the phenyl ring coupled to the thiazole ring were observed at $\delta 126.0,128.4$, 129.2 and 134.2. A combination of elemental analysis (C, H, N), UV, IR and HRMS confirmed the purity and identity of all the compounds.

\subsection{X-ray crystallography}

The X-ray crystal structure of 2-(2-(pyridin-2-ylmethylene) hydrazinyl)-4-(4-tolyl)-1,3-thiazole (4) is shown in Fig. 2. Crystal and refinement data are summarized in Table 1 . The dihedral angles $\mathrm{C}(11)-\mathrm{C}(10)-\mathrm{C}(9)-\mathrm{N}(4), \mathrm{C}(9)-\mathrm{N}(4)-\mathrm{C}(7)-\mathrm{N}(3), \mathrm{C}(7)-\mathrm{N}(3)-\mathrm{N}(2)-$ $\mathrm{C}(6), \quad \mathrm{N}(2)-\mathrm{C}(6)-\mathrm{C}(5)-\mathrm{C}(4) \quad$ and $\mathrm{C}(16)-\mathrm{C}(13)-\mathrm{C}(12)-\mathrm{C}(11)$ of $-177.84^{\circ},-179.48^{\circ},-176.60^{\circ},-176.54^{\circ}$ and $178.43^{\circ}$ respectively indicate that the molecule is close to planar. In the thiazole ring, two significantly different $\mathrm{C}-\mathrm{N}$ bonds are found viz. C9-N4 (1.373(4) $\AA$ ) and $\mathrm{C} 7=\mathrm{N} 4(1.265(5) \AA)$ and C8 $=\mathrm{C} 9$ is clearly a double bond $(1.348(5) \AA)$. It is apparent that compound (4) crystallises in the $\mathrm{Z}$-isomeric form where intramolecular $\mathrm{H}$-bonding with the pyridyl ring and the proton attached to N2 is seen (see Fig. 2). In this case, the $E$-isomer cannot be stabilised by $\mathrm{H}$-bonding due to the loss of the proton from $\mathrm{N}^{4}$ of the parent thiosemicarbazone.

\subsection{Structure-activity relationships (SAR)}

To investigate the importance of substituents on the phenyl ring for the antiparasitic activity against trypomastigote form, compound (3) (without substituents) was compared with seven para substituted analogues. It was found that compounds (5), (6), (8) and (9) showed better anti-T. cruzi activity than (3), while compounds (4), (7) and (13) were less potent (see Table 2). For the chloro substituted compounds (9-11), it was observed that the dichloro compounds (10 and 11) were equally trypanocidal, being 3-fold more potent than 2-(2-(pyridin-2-ylmethylene)hydrazinyl)-4-(4chlorophenyl)-1,3-thiazole (9). The monobromo compounds (5) and (6) displayed activity intermediate of the mono and dichloro compounds. The presence of a methyl group attached to C8 (for compound 5) did not significantly affect biological activity.

Comparing compound (14) with (3) (naphthyl and aryl, respectively), it was observed that the influence of a more bulky substituent increased the trypanocidal activity, probably because of an increase in lipophilicity. For the nitro compounds (12) and (13), the position of the substituent affected trypanocidal activity. For compound (12), (meta substituted), a 2-fold increase in activity was found relative to (13) (para substituted).

Compounds (15) to (26) (derived from 2-acetyl pyridine) differed from compounds (3) to (14) (derived from 2-pyridine carbaldehyde) by a methyl group present in C6 (Scheme 1). Analysis of the activity of these compounds suggests a trend in which a

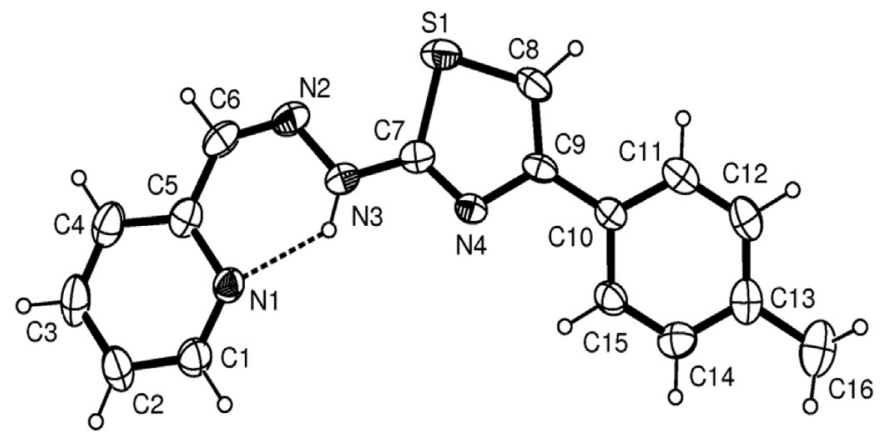

Fig. 2. ORTEP view of compound (4) showing intramolecular H-bonding (30\% probability ellipsoids are shown).
Table 1

Crystal data and structure refinement for compound (4).

\begin{tabular}{|c|c|}
\hline Empirical formula & $\mathrm{C}_{16} \mathrm{H}_{14} \mathrm{~N}_{4} \mathrm{~S}$ \\
\hline Formula weight & 294.37 \\
\hline Temperature (K) & $296(2)$ \\
\hline Wavelength $(\AA)$ & 0.71073 \\
\hline Crystal system & Orthorhombic \\
\hline Space group & Pna $2_{1}$ \\
\hline \multicolumn{2}{|l|}{ Unit cell dimensions } \\
\hline$a(\AA)$ & $9.858(1)$ \\
\hline$b(\AA)$ & $25.602(3)$ \\
\hline$c(\AA)$ & $5.5127(6)$ \\
\hline Volume $\left(\AA^{3}\right)$ & $1391.3(3)$ \\
\hline$Z$ & 4 \\
\hline$\rho_{\text {calc }}\left(\mathrm{g} \mathrm{cm}^{-3}\right)$ & 1.405 \\
\hline$\mu\left(\mathrm{mm}^{-1}\right)$ & 0.231 \\
\hline $\mathrm{F}(000)$ & 616 \\
\hline Crystal size (mm) & $0.6 \times 0.1 \times 0.1$ \\
\hline$\theta$ range $\left(^{\circ}\right)$ & $3.2-25.0$ \\
\hline Reflections collected & 5864 \\
\hline Independent reflections & 2635 \\
\hline Observed reflections $[I>2 \sigma(I)]$ & 1489 \\
\hline$R_{\text {int }}$ & 0.0590 \\
\hline Refinement method & Full-matrix least-squares on $\mathrm{F}^{2}$ \\
\hline Data/restraints/parameters & $2635 / 1 / 191$ \\
\hline Goodness-of-fit on $\mathrm{F}^{2}$ & 0.997 \\
\hline$R[I>2 \sigma(I)]$ & 0.0580 \\
\hline$w R_{2}$ (all data) & 0.0871 \\
\hline Absolute structure parameter & $-0.03(11)$ \\
\hline Residual extrema $\left(\mathrm{e} \AA^{-3}\right)$ & 0.183 and -0.144 \\
\hline CCDC number & 980106 \\
\hline
\end{tabular}

methyl in C6 increases the trypanocidal activity. Compounds (15)-(26) stand out, show high trypanocidal activity (trypomastigote form); with exception of (25), all compounds are more potent than reference drug benznidazole.

Table 2

Anti T. cruzi activities of acetylpyridin-2-yl thiosemicarbazone (2a) and 2-(pyridin2-yl)-1,3-thiazoles (3-14).

\begin{tabular}{llll}
\hline Compd. & $\mathrm{Ar}$ & $\frac{\text { Y strain T. cruzi, } \mathrm{IC}_{50}(\mu \mathrm{M})}{\text { Trypomastigotes }^{\mathrm{a}} \quad \text { Epimastigotes }^{\mathrm{b}}}$ & $\frac{\text { HepG2, } \mathrm{IC}_{50}}{(\mu \mathrm{M})^{c}}$ \\
\hline
\end{tabular}
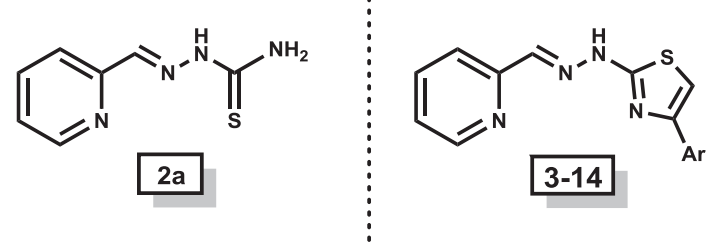

\begin{tabular}{|c|c|c|c|c|}
\hline $2 a$ & - & 17.3 & 119.5 & ND \\
\hline 3 & $\mathrm{Ph}$ & 5.4 & 8.3 & 100 \\
\hline 4 & 4- $\mathrm{CH}_{3} \mathrm{Ph}$ & 16.8 & 3.8 & 100 \\
\hline 5 & 4-BrPh & 2.2 & 2.2 & 100 \\
\hline 6 & $4-\mathrm{BrPh}^{\mathrm{d}}$ & 2.6 & 18.3 & 100 \\
\hline 7 & 4-FPh & 72.7 & 3.5 & 18.20 \\
\hline 8 & $4-\mathrm{CH}_{3} \mathrm{OPh}$ & 4.8 & 5.6 & 100 \\
\hline 9 & 4-ClPh & 3.8 & 3.8 & 100 \\
\hline 10 & 2,4-diClPh & 1.2 & 4.8 & 100 \\
\hline 11 & 3,4-diClPh & 1.2 & 4 & 100 \\
\hline 12 & $3-\mathrm{NO}_{2} \mathrm{Ph}$ & 74.2 & 2.5 & 100 \\
\hline 13 & $4-\mathrm{NO}_{2} \mathrm{Ph}$ & 152.9 & 4.4 & 100 \\
\hline 14 & 2-Naphthyl & 2.1 & 8.3 & 100 \\
\hline Bdz & - & 6.2 & 6.6 & ND \\
\hline
\end{tabular}

a Determined $24 \mathrm{~h}$ after incubation of trypomastigotes with the compounds.

b Determined 11 days after incubation of epimastigotes with the compounds. $\mathrm{IC}_{50}$ was calculated from at least five concentrations, in triplicate (SD $<10 \%)$.

${ }^{c} \mathrm{IC}_{50}$ determined for human Hepg2 after $48 \mathrm{~h}$ of incubation in the presence of the compounds.

${ }^{\mathrm{d}}$ R: methyl, see Scheme 1. Bdz: benznidazole. ND: not determined. 
Table 3

Anti T. cruzi Activities of acetylpyridin-2-yl thiosemicarbazone (2b) and 2-(pyridin2-yl)-1,3-thiazoles (15-26).

\begin{tabular}{llll}
\hline Compd. Ar & Y strain T. cruzi, $\mathrm{IC}_{50}(\mu \mathrm{M})$ & HepG2, IC $50(\mu \mathrm{M})^{\mathrm{c}}$ \\
\cline { 2 - 4 } & Trypomastigotes $^{\mathrm{a}}$ Epimastigotes $^{\mathrm{b}}$ & \\
\hline
\end{tabular}<smiles>C/C(=N\NC(N)=S)c1ccccn1</smiles><smiles>C/C(=N\Nc1nc(Br)cs1)c1ccccn1</smiles>

$2 \mathbf{b}$
15
16
17
18
19
20
21
22
23
24
25
26
Bd

$\begin{array}{lrrc}- & 2.8 & 4.5 & \text { ND } \\ \mathrm{Ph} & 1.1 & 2.7 & 91.20 \\ 4-\mathrm{CH}_{3} \mathrm{Ph} & 1.7 & 2.5 & 100 \\ 4-\mathrm{BrPh}^{\mathrm{P}} & 2.1 & 2.1 & 100 \\ 4-\mathrm{BrPh}^{\mathrm{d}} & 2.3 & 2.3 & 85.11 \\ 4-\mathrm{FPh} & 3.8 & 2.8 & 91.20 \\ 4-\mathrm{CH}_{3} \mathrm{OPh} & 2.1 & 14.7 & 100 \\ 4-\mathrm{ClPh} & 2.1 & 2.5 & 100 \\ 2,4-d i \mathrm{ClPh} & 1.9 & 14.9 & 100 \\ 3,4-d i \mathrm{ClPh} & 3.1 & 5.0 & 100 \\ 3-\mathrm{NO}_{2} \mathrm{Ph} & 3.9 & 2.4 & 100 \\ 4-\mathrm{NO}_{2} \mathrm{Ph} & 36.7 & 5.2 & 100 \\ \text { 2- } \mathrm{Naphthyl} & 2.0 & 4.1 & 100 \\ - & 6.2 & 6.6 & \mathrm{ND}\end{array}$

a Determined $24 \mathrm{~h}$ after incubation of trypomastigotes with the compounds.

b Determined 11 days after incubation of epimastigotes with the compounds. IC $\mathrm{C}_{50}$ was calculated from at least five concentrations, in triplicate (SD $<10 \%$ ).

${ }^{c} \mathrm{IC}_{50}$ determined for human Hepg2 after $48 \mathrm{~h}$ of incubation in the presence of the compounds.

d R: methyl, see Scheme 1. Bdz: benznidazole. Percentage of inhibition is the average of triplicate runs determined in one experiment. ND: not determined.

The para substituted 2-(pyridin-2-yl)-1,3-thiazoles (16-21 and 25) were less active than unsubstituted (2-(1-(pyridin-2-yl) ethylene)hydrazinyl)-4-phenyl-1,3-thiazole (15), which was the most potent compound tested in this work. No correlation was observed between the electron withdrawing properties of the substituent and trypanocidal activity.

For the isomeric dichloro compounds (22) and (23), we observed little change in trypanocidal activity. For the nitro compounds (24 and 25), the compound meta substituted (24) was 9fold more potent than para substituted (25), (3.9 $\mu \mathrm{M}$ vs $36.7 \mu \mathrm{M}$ respectively).

From Table 3, it can be seen that (2-(pyridin-2-yl)ethylene)-1,3thiazoles (15-26) (with a methyl attached to C6), had increased the trypanocidal activity for both trypomastigote and epimastigote in comparison with (2-(pyridin-2-yl)methylene)-1,3-thiazoles (3-14).
Comparing compounds with nitro substituents across the (3-14) and (15-26) series, the biggest difference was observed for compounds (13/25) (meta substituted), with $3.9 \mu \mathrm{M}$ against $74.2 \mu \mathrm{M}$ and (12/25), para substituted, with $36.7 \mu \mathrm{M}$ against $152.9 \mu \mathrm{M}$.

Among all of the compounds in this work, the most potent were (10), (11) and (15). It should be noted that among twenty-four compounds designed for anti-Chagas activity, twenty compounds $(3,5,6,8-11,14,15-24$ and 26$)$ displayed better trypanocidal activity than benznidazole.

Analysing the antiparasitic activity against epimastigote form, benznidazole, which is the reference drug, exhibited an $\mathrm{IC}_{50}$ of $6.6 \mu \mathrm{M}$. Once again, the majority of derivatives were very active. In this case, only compounds (6), (20) and (22) were several times less potent than benznidazole. In contrast, compounds (5), (12), (15)-(19) and (21) displayed a better activity profile than benznidazole-treated parasites.

A recent work describing 2-imino-1,3-thiazoles [16] (derivatives 26-46), that share an aryloxypropylimine instead of a pyridine ring, displayed lower trypanocidal effects when compared to these that possess a 2-pyridyl moiety, pointing out the importance of the 2-pyridyl moiety for the trypanocidal activity. Fig. 3 summarizes the main SAR for anti T. cruzi activity (tripomastigote form).

\subsection{Cruzain inhibition activity}

Table 4 shows the inhibition of the enzyme cruzain of T. cruzi (TCC). The experimental protocol described by Ferreira [26] was utilized in this assay. All compounds were tested at a concentration of $100 \mu \mathrm{M}$, except for cases limited by solubility, in which the screening was performed at either 50 or $75 \mu \mathrm{M}$ (as noted on Table 4). Compounds which inhibited enzyme activity by at least $70 \%$ in the screening had their $\mathrm{IC}_{50}$ determined.

Some works describe that 2-imino-1,3-thiazoles are trypanocidal agents by altering the ergosterol biosynthesis instead of inhibiting the catalytic activity of cruzain $[16,19]$. In this work we show that cruzain is potently inhibited by several compounds.

Among all compounds tested, the most actives were (20) and (26), showing the lowest $\mathrm{IC}_{50}$ values $(0.04 \pm 0.03 \mu \mathrm{M}$ and $0.01 \mu \mathrm{M}$, respectively). Due to the low potency of some compounds and the absence of $\mathrm{IC}_{50}$ values, in some cases we made a discussion based in percentual inhibition of cruzain.

Comparing para substituted compounds; the most active were (20), (16), (19) and (5), showing percentage of inhibition near $90 \%$. For the dichloro compounds (10-11), 2-(2-(pyridin-2-ylmethylene) hydrazinyl)-4-(2,4-dichlorophenyl)-1,3-thiazole (10) did not show any inhibition of cruzain, in contrast to 2-(2-(pyridin-2ylmethylene)hydrazinyl)-4-(3,4-dichlorophenyl)-1,3-thiazole (11), which displayed weak inhibition. For the nitro compounds (12-13),

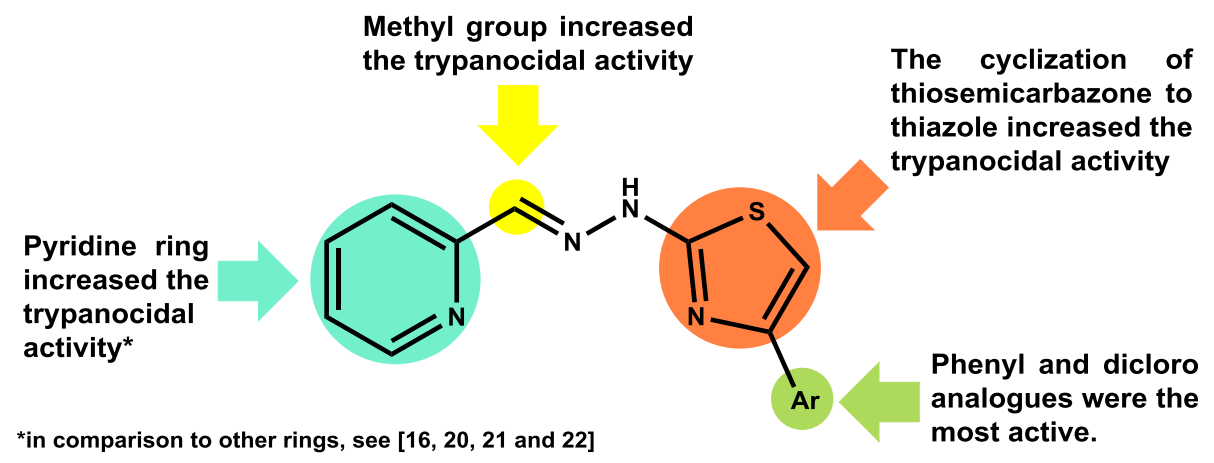

Fig. 3. Summary of SAR of trypanocidal activity for compounds (3-26). 
the positional change of the nitro group from para to meta had a huge impact on potency against cruzain: while the 2-(2-(pyridin-2ylmethylene)hydrazinyl)-4-(3-nitrophenyl)-1,3-thiazole shows $\mathrm{IC}_{50}=1.3 \pm 0.7 \mu \mathrm{M}, 2$-(2-(pyridin-2-ylmethylene)hydrazinyl)-4-(4-nitrophenyl)-1,3-thiazole (13) does not considerably inhibit the enzyme at $100 \mu \mathrm{M}$.

To investigate the relative activity of thiosemicarbazone vs thiazole in cruzain inhibition, compounds (2a) and (3) were compared. Neither of these compounds inhibits the enzyme at the concentrations evaluated, but (15), an analogue of (3) differing only by the addition of a methyl group at $\mathrm{C} 6$ was shown to be a moderately potent inhibitor $\mathrm{IC}_{50}=1.3 \pm 0.7 \mu \mathrm{M}$. Extrapolating the

\section{Table 4}

Comparison of in vitro cruzain inhibition activity of compounds (2a-2b) and (3-26).

\begin{tabular}{llll}
\hline Compd. & $\mathrm{Ar}$ & \% Cruzain inhibition at $100 \mu \mathrm{M}^{\mathrm{a}}$ & $\mathrm{IC}_{50}(\mu \mathrm{M})^{\mathrm{d}}$ \\
\hline
\end{tabular}<smiles>NC(=S)N/N=C/c1ccccn1</smiles>

$2 a$<smiles>C/C(=N\NC(N)=S)c1ccccn1</smiles>

\section{2a}<smiles>Brc1csc(N/N=C/c2ccccn2)n1</smiles>

\section{$1 \pm 2$}

$5 \pm 5$<smiles>C/C(=N\Nc1nc(Br)cs1)c1ccccn1</smiles>

ND

ND

\begin{tabular}{llrl}
$\mathbf{3}$ & $\mathrm{Ph}$ & $9 \pm 1^{\mathrm{b}}$ & $\mathrm{ND}$ \\
$\mathbf{1 5}$ & $\mathrm{Ph}$ & $93 \pm 3$ & $1.3 \pm 0.7$ \\
$\mathbf{4}$ & $4-\mathrm{CH}_{3} \mathrm{Ph}$ & $23 \pm 2$ & $\mathrm{ND}$ \\
$\mathbf{1 6}$ & $4-\mathrm{CH}_{3} \mathrm{Ph}$ & $90 \pm 4$ & $0.4 \pm 0.2$ \\
$\mathbf{5}$ & $4-\mathrm{BrPh}$ & $86 \pm 6$ & $9.5 \pm 7.5$ \\
$\mathbf{1 7}$ & $4-\mathrm{BrPh}$ & $-8 \pm 2$ & $\mathrm{ND}$ \\
$\mathbf{6}$ & $4-\mathrm{BrPh}^{\mathrm{e}}$ & $10 \pm 4$ & $\mathrm{ND}$ \\
$\mathbf{1 8}$ & $4-\mathrm{BrPh}^{\mathrm{e}}$ & $27 \pm 3$ & $\mathrm{ND}$ \\
$\mathbf{7}$ & $4-\mathrm{FPh}$ & $22 \pm 3^{\mathrm{c}}$ & $\mathrm{ND}$ \\
$\mathbf{1 9}$ & $4-\mathrm{FPh}$ & $89 \pm 5$ & $0.3 \pm 0.2$ \\
$\mathbf{8}$ & $4-\mathrm{CH}_{3} \mathrm{OPh}$ & $20 \pm 1^{\mathrm{b}}$ & $\mathrm{ND}$ \\
$\mathbf{2 0}$ & $4-\mathrm{CH}_{3} \mathrm{OPh}$ & $95 \pm 2$ & $0.04 \pm 0.03$ \\
$\mathbf{9}$ & $4-\mathrm{ClPh}_{2}$ & $-1 \pm 4^{\mathrm{b}}$ & $\mathrm{ND}$ \\
$\mathbf{2 1}$ & $4-\mathrm{ClPh}_{\mathbf{P} h}$ & $-3 \pm 1$ & $\mathrm{ND}$ \\
$\mathbf{1 0}$ & $2,4-d i \mathrm{ClPh}$ & $0 \pm 3^{\mathrm{b}}$ & $\mathrm{ND}$ \\
$\mathbf{2 2}$ & $2,4-d i \mathrm{ClPh}$ & $81 \pm 7$ & $4.8 \pm 3.8$ \\
$\mathbf{1 1}$ & $3,4-d i \mathrm{ClPh}$ & $21 \pm 9$ & $\mathrm{ND}$ \\
$\mathbf{2 3}$ & $3,4-d i \mathrm{ClPh}$ & $89 \pm 4$ & $0.4 \pm 0.1$ \\
$\mathbf{1 2}$ & $3-\mathrm{NO}_{2} \mathrm{Ph}$ & $85 \pm 2$ & $1.3 \pm 0.7$ \\
$\mathbf{2 4}$ & $3-\mathrm{NO}_{2} \mathrm{Ph}$ & $10 \pm 5^{\mathrm{b}}$ & $\mathrm{ND}$ \\
$\mathbf{1 3}$ & $4-\mathrm{NO}_{2} \mathrm{Ph}$ & $12 \pm 3$ & $\mathrm{ND}$ \\
$\mathbf{2 5}$ & $4-\mathrm{NO}_{2} \mathrm{Ph}$ & $11 \pm 5^{\mathrm{b}}$ & $\mathrm{ND}$ \\
$\mathbf{1 4}$ & $2-\mathrm{Naphthyl}_{\mathbf{2 6}}$ & $3 \pm 1$ & $\mathrm{ND}$ \\
$\mathbf{2 6}$ & $2-\mathrm{Naphthyl}^{\mathbf{b}}$ & $94 \pm 3$ & 0.01 \\
\hline
\end{tabular}

${ }^{a}$ Values correspond to the average of six measurements, from two independent experiments, each one in triplicate. Errors are given by the ration between the standard deviation and the square root of the number of measurements. Compounds evaluated at $100 \mu \mathrm{M}$ unless otherwise noted.

b Compounds evaluated at $75 \mu \mathrm{M}$.

c Compounds evaluated at $50 \mu \mathrm{M}$.

${ }^{d}{ } \mathrm{IC}_{50}$ curves were determined based two independent experiments, each one involving at least seven compound concentrations in triplicates.

e R: methyl, see Scheme 1. ND: not determined. analysis by comparison of compounds (3-14) to compounds (15-26), which show an analogous difference, we observe that in seven cases the addition of the methyl considerably improved cruzain inhibition, while only for two compound pairs (5 vs 17 and 12 vs 24) the opposite effect was observed. Together, these results indicate the high importance of the methyl group at C6.

Within the series $(\mathbf{1 5}-\mathbf{2 6})$, seven compounds had their $\mathrm{IC}_{50}$ values determined, and in five cases the potency was better than $0.5 \mu \mathrm{M}$. Among the para substituted compounds, (16) and (19) had very similar potencies. On the other hand, modifying the methyl substituent (16) to methoxy (20) increased the potency by an order of magnitude.

For chlorine substituted compounds (21-23), the pattern of substitution had a big impact on potency. While the para substituted compound was inactive, disubstituted compounds were cruzain inhibitors, and the 3,4-diCl compound (23) was 12 fold more potent than the 2,4-diCl (22). Comparing the isomeric nitro-compounds (meta (24) and para (25) substituted), no significant cruzain inhibition was observed.

\subsection{Cytotoxicity activity}

To determine the toxicity profile of the compounds, cytotoxicity assay adapted from Ballell et al. [27] were performed with HepG2 cells, a human liver cell line commonly used for in vitro testing of toxicity [28]. Cells were incubated with the compounds at concentration of $100 \mu \mathrm{M}$ for $48 \mathrm{~h}$. It is worth mentioning that a compound that can kill parasites is necessary but not sufficient to represent a good drug lead unless it also demonstrates low or nontoxicity among other criteria. As can be observed in Tables 2 and 3, only compound (7) (a fluorine derivative) exhibited toxicity for HepG2 $(18.20 \mu \mathrm{M})$. The most of compounds were less cytotoxic for HepG2 at concentrations up to $85.11 \mu \mathrm{M}$, demonstrating the low toxicity profile of the compounds assayed.

\subsection{Docking studies}

In order to understand a probable mechanism of action, we investigated the interaction of these compounds with cruzain (PDB ID: 3IUT) by docking studies. The binding mode for the ligands was determined as the highest (most positive) score among the possible solutions for each ligand, generated according to the CHEMPLP Score Function [29]. Fig. 4 shows the superposition of the best

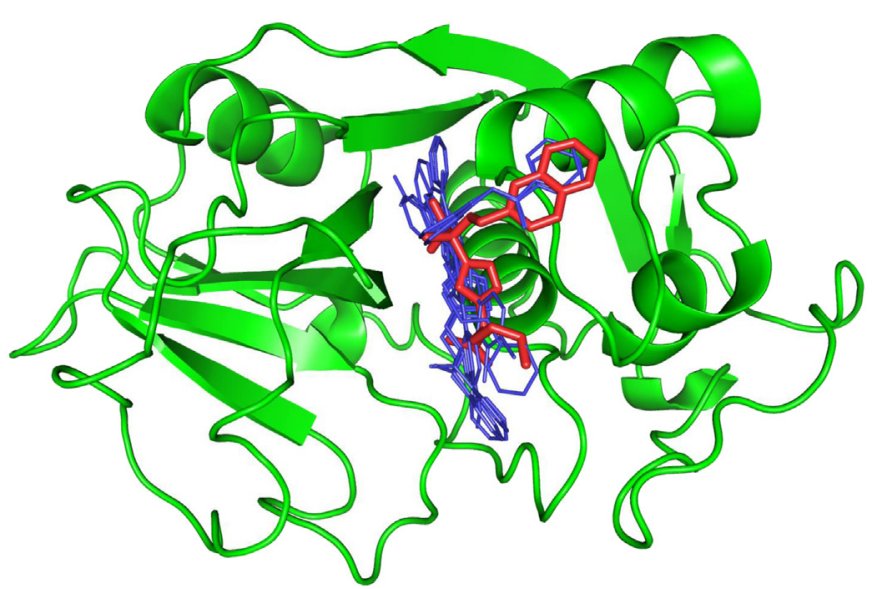

Fig. 4. Superposition of the docking solutions for cruzain-inhibiting compounds (5), (12), (15), (16), (19), (20), (22), (23) and (26) (blue structures) bound to cruzain (green) and the crystallographic structure of the "KB2" cocrystallized ligand [30] (red structure). (For interpretation of the references to colour in this figure legend, the reader is referred to the web version of this article.) 


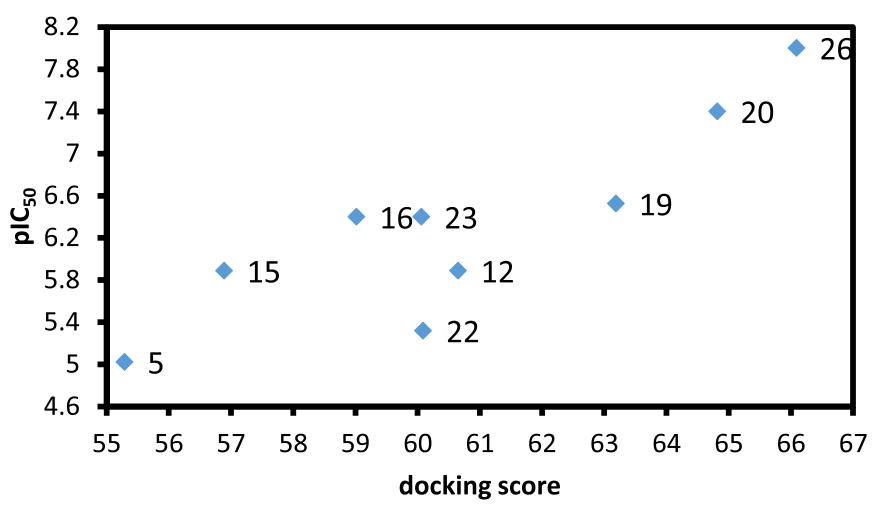

Fig. 5. Trend observed between the in vitro ( $\mathrm{pIC}_{50}$ for cruzain inhibition) and in silico (docking score) results, for compounds (5), (12), (15), (16), (19), (20), (22), (23) and (26).

docking solutions for compounds that have $\mathrm{IC}_{50}$ values experimentally determined for cruzain $(5,12,15,16,19,20,22,23,26)$ and the crystallographic structure of the "KB2", a high-efficient cruzain inhibitor cocrystallized ligand [30]. To compare in silico vs in vitro cruzain data, $\mathrm{IC}_{50}$ values were first converted into $\mathrm{pIC}_{50}$ values (equals $-\log _{10} \mathrm{IC}_{50}$ for cruzain inhibition, in units of moles per litre).

Fig. 5 shows the trend between the calculated docking scores and the experimental $\mathrm{pIC}_{50}$ data, which indicates the compounds with the highest $\mathrm{pIC}_{50}$ being most active. There is a clear correlation between the docking score and $\mathrm{pIC}_{50}$ supporting the hypothesis that the most tightly binding thiazoles are also the most potent cruzain inhibitors (i.e., greater in vitro $\mathrm{pIC}_{50}$ values).

To identify the molecular reasons for the two extremes of potency, the highest (26) $\left(\mathrm{IC}_{50}=0.01 \mathrm{nM}\right)$ and lowest (5) $\left(\mathrm{IC}_{50}=9.5 \mathrm{nM}\right)$ in vitro results, we performed a detailed analysis of the intermolecular interactions with the cruzain target. The principle structural differences between these two molecules are as follows: (i) the presence of a 4-bromophenyl ring linked to the thiazole ring in molecule (5), instead of a naphthalene group in molecule (26); (ii) a methyl group on C6 (adjacent to the pyridyl ring) for molecule (26), rather than hydrogen for molecule (5).

The difference between the binding modes of these two molecules is show in detail in Fig. 6 and Table 5. It appears that the large hydrophobic naphthalene group in molecule (26) provides a greater contact surface for interactions with hydrophobic residues LEU67, MET68, ALA138 and LEU160 in the S2 cruzain subsite, which is known to accommodate hydrophobic groups. Compared with the bromophenyl group in (5). The hydrogen bond with the residue ASP161 is slightly shorter for the molecule (26) (2.5 $\AA$ ) than for molecule (5) (2.8 $\AA$ ). There is also a weak hydrogen bond with the CYS25 residue (3.4 $\AA$ ). These finding imbue greater stability to the complex formed with (26) than (5), with docking scores of 66.09 and 55.29, respectively. These findings corroborate the in vitro binding assay with the cruzain enzyme.

\section{Conclusion}

The current investigation has revealed novel structure-activity relationships regarding aromatic substitution at the phenyl moiety of 2-(pyridin-2-yl)-1,3-thiazoles for the design of new drugs for the treatment of Chagas disease. The novel analogues (3-26) exhibited improve trypanocidal activity than thiosemicarbazones (2a-b), while showing a similar potency to standard drug in use for treatment of Chagas disease, Benznidazole.

Compounds (10) and (11) were the most potent thiazoles with $\mathrm{IC}_{50}$ values of $1.2 \mu \mathrm{M}$ for each compound. In addition, all of the novel thiazoles showed similar or greater trypanocidal efficacy than Benznidazole, with compounds (10) and (11) exhibiting highest efficacies overall.

Structure-activity analysis did not reveal a correlation between ligands with electron-donating or electron-withdrawing substituents in terms of trypanocidal activity. However, the in silico docking studies corroborate with in vitro cruzain inhibition, showing that the molecules with more stable or positive docking scores (i.e., greater in silico affinity for cruzain) are also the most potent cruzain inhibitors (i.e., greater in vitro $\mathrm{pIC}_{50}$ values).

\section{Experimental section}

\subsection{Equipment and reagents}

All reagents were used as purchased from commercial sources (Sigma-Aldrich, Acros Organics, Vetec or Fluka). Progress of the reactions was followed by thin-layer chromatography (TLC) analysis (Merck, silica gel $60 \mathrm{~F}_{254}$ in aluminium foil). Purity of the target compounds was confirmed by combustion analysis (for C, H, N, S) performed by a Carlo-Erba instrument (model EA 1110). Melting points were determined on a Fisatom 430D electrothermal capillary melting point apparatus and were uncorrected. NMR spectra were measured on either a Varian UnityPlus $400 \mathrm{MHz}$ ( $400 \mathrm{MHz}$ for

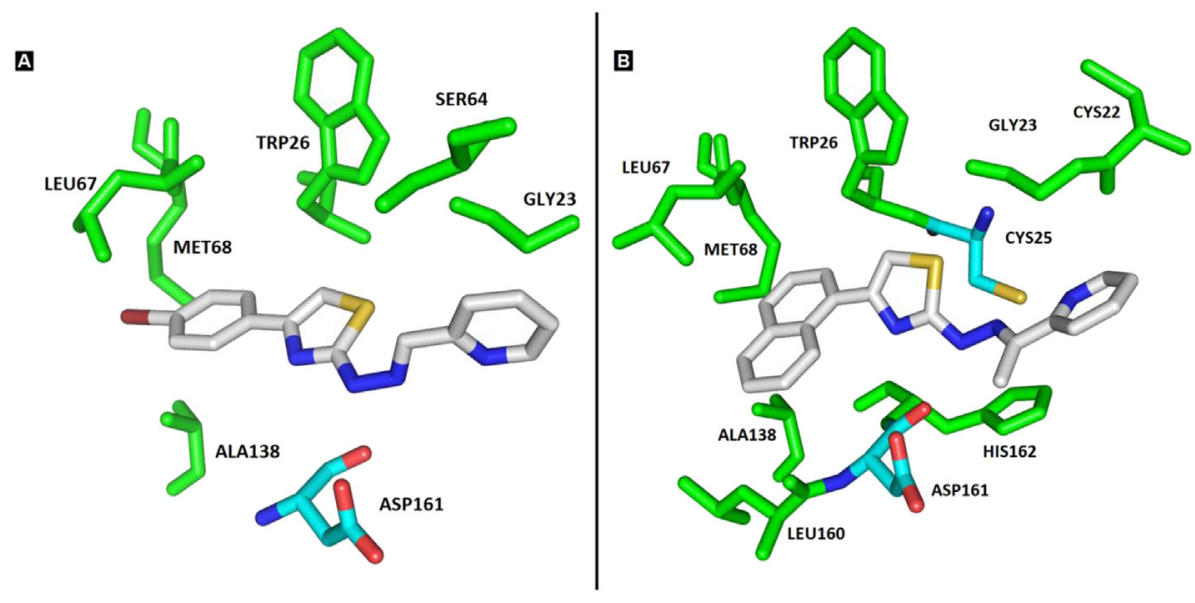

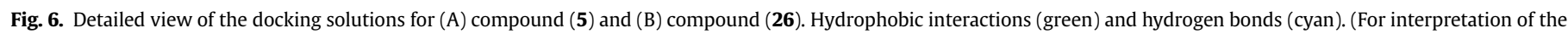
references to colour in this figure legend, the reader is referred to the web version of this article.) 
Table 5

Docking scores and molecular interactions between cruzain and molecules (5) and (26). ${ }^{\mathrm{a}}$

\begin{tabular}{lll}
\hline Cruzain residues & \multicolumn{2}{l}{ Molecules } \\
\cline { 2 - 3 } & 5 & 26 \\
\hline CYS22 & - & $\mathrm{HC}$ \\
GLY23 & $\mathrm{HC}$ & $\mathrm{HC}$ \\
CYS25 & - & 3.4 \\
TRP26 & $\mathrm{HC}$ & $\mathrm{HC}$ \\
SER64 & $\mathrm{HC}$ & - \\
LEU67 & $\mathrm{HC}$ & $\mathrm{HC}$ \\
MET68 & $\mathrm{HC}$ & $\mathrm{HC}$ \\
ALA138 & $\mathrm{HC}$ & $\mathrm{HC}$ \\
LEU160 & - & $\mathrm{HC}$ \\
ASP161 & 2.8 & 2.5 \\
HIS162 & - & $\mathrm{HC}$ \\
SCORES & 55.29 & 66.09 \\
\hline
\end{tabular}

a $\mathrm{HC}$ means "hydrophobic contacts" and the numbers are the hydrogen bond distances, in Ångstroms.

${ }^{1} \mathrm{H}$ and $100 \mathrm{MHz}$ for ${ }^{13} \mathrm{C}$ ) or a Bruker AMX-300 MHz (300 MHz for ${ }^{1} \mathrm{H}$ and $75.5 \mathrm{MHz}$ for ${ }^{13} \mathrm{C}$ ) instruments. DMSO- $d_{6}$ and $\mathrm{D}_{2} \mathrm{O}$ were purchased from CIL or Sigma-Aldrich. Chemical shifts are reported in $\mathrm{ppm}$ and multiplicities are given as $\mathrm{s}$ (singlet), $\mathrm{d}$ (doublet), $\mathrm{t}$ (triplet), m (multiplet), dd (double doublet), and coupling constants $(J)$ in hertz. Mass spectrometry experiments were performed on a LC-IT-TOF (Shimadzu). Unless otherwise specified, ESI was carried out in the positive ion mode. Typical conditions were: capillary voltage of $3 \mathrm{kV}$ and cone voltage of $30 \mathrm{~V}$, and peak scan between 50 and $1000 \mathrm{~m} / z$. IR spectra were recorded with a Brucker model IFS66 FT-IR spectrophotometer using $\mathrm{KBr}$ pellets.

\subsection{Crystallography}

Crystallographic data were collected on an Oxford Diffraction Gemini S Ultra CCD diffractometer at $296 \mathrm{~K}$ using MoK $\alpha$ radiation $\left(2 \theta_{\max }=50^{\circ}\right)$. Data reduction and empirical absorption corrections were carried out with the CrysAlis Pro program (Oxford Diffraction vs 171.33.42). The structure was solved by direct methods with SHELXS86 and refined with SHELXL97 [31]. All non-H-atoms were refined anisotropically and $\mathrm{H}$-atoms were constrained at their estimated positions using a riding model. The thermal ellipsoid diagram was generated with ORTEP3 [32]. All crystallographic calculations were carried out within the WinGX graphical user interface [33]. Crystallographic data of compound (4) have been deposited with the Cambridge Crystallographic Data Centre as supplementary publication CCDC 980106 . These data can be obtained free of charge from The Cambridge Crystallographic Data Centre ((Cambridge, UK) via www.ccdc.cam.ac.uk).

\subsection{General modified procedure for the synthesis of known thiosemicarbazones (2a-b)}

To a solution of 2-pyridine carbaldehyde $(0.75 \mathrm{~g}, 7 \mathrm{mmol}$ ) (or acetyl-2-pyridine $(0.85 \mathrm{~g}, 7 \mathrm{mmol}))$ in 2-propanol $(10 \mathrm{~mL})$ was added thiosemicarbazide $(0.64 \mathrm{~g}, 7 \mathrm{mmol})$ and few drops of acetic acid. The reaction vessel was placed in an ultrasonic bath $(40 \mathrm{MHz}$, $180 \mathrm{~V}$ ) and irradiated for $120 \mathrm{~min}$, at r.t. The precipitate was filtered off, washed with hexane then dried in desiccator under vacuum. Additional amount of desired compound could be recovered from the filtrate after cooling.

\subsubsection{2-(Pyridin-2-ylmethylene)hydrazinecarbothioamide (2a)}

Crystallization from toluene/hexane 7:3, afforded yellow crystals, yield: $91 \%$ m.p. $\left({ }^{\circ} \mathrm{C}\right)$ : 167 . IR $(\mathrm{KBr}):(\mathrm{C}=\mathrm{C}), 1606(\mathrm{C}=\mathrm{N}),(\mathrm{N}-\mathrm{H})$ $\mathrm{cm}^{-1} .{ }^{1} \mathrm{H}$ NMR (300 MHz, DMSO- $\left.d_{6}\right), \delta \mathrm{ppm}: 7.35(\mathrm{t}, J=4.9 \mathrm{~Hz}, 1 \mathrm{H}$, Ar), $7.81(\mathrm{t}, J=7.7 \mathrm{~Hz}, 1 \mathrm{H}, \mathrm{Ar}), 8.09(\mathrm{~s}, 1 \mathrm{H}, \mathrm{CH}), 8.16$ (broad s, $1 \mathrm{H}$, $\mathrm{NH}_{2}$ ), 8.26 (d, $J=8.0 \mathrm{~Hz}, 1 \mathrm{H}, \mathrm{Ar}$ ), 8.35 (broad s, $1 \mathrm{H}, \mathrm{NH}_{2}$ ), 8.55 (d, $J=4.9 \mathrm{~Hz}, 1 \mathrm{H}, \mathrm{Ar}), 11.63(\mathrm{~s}, 1 \mathrm{H}, \mathrm{NH}) .{ }^{13} \mathrm{C}$ NMR $\left(75.5 \mathrm{MHz}\right.$, DMSO-d $\mathrm{d}_{6}$, $\delta$ ppm: 120.2 (C, Ar), 124.0 (C, Ar), 136.5 (C, Ar), $142.5(\mathrm{C}=\mathrm{N}), 149.2$ (C, $\mathrm{Ar}$ ), 153.3 (C, $\mathrm{Ar}$ ), 178.3 ( $\mathrm{C}=\mathrm{S}, \mathrm{Ar}$ ). Anal. Calcd for $\mathrm{C}_{7} \mathrm{H}_{8} \mathrm{~N}_{4} \mathrm{~S}$ : C, 46.65; H, 4.47; N, 31.09; S, 17.79; found: C, 46.58; H, 4.50; N, 31.12; S, 17.71. HR-MS (ESI): $181.6730[\mathrm{M}+\mathrm{H}]^{+}$.

\subsubsection{2-[1-(2-Pyridinyl)ethylidene]hydrazinecarbothioamide (2b)}

Crystallization from toluene/hexane 7:3, afforded yellow crystals, Yield: $86 \%$, m.p. $\left({ }^{\circ} \mathrm{C}\right): 170$. IR $\left(\mathrm{KBr}, \mathrm{cm}^{-1}\right): 1553(\mathrm{C}=\mathrm{C}), 1612$ $(\mathrm{C}=\mathrm{N}), 3066(\mathrm{~N}-\mathrm{H}) .{ }^{1} \mathrm{H}$ NMR (300 MHz, DMSO-d 6 ), $\delta$ ppm: 2.37 (s, $\left.3 \mathrm{H}, \mathrm{CH}_{3}\right), 7.37(\mathrm{t}, J=6.1 \mathrm{~Hz}, 1 \mathrm{H}, \mathrm{Ar}), 7.77(\mathrm{t}, J=7.8 \mathrm{~Hz}, 1 \mathrm{H}, \mathrm{Ar}), 8.12$ (broad s, 1H, $\mathrm{NH}_{2}$ ), 8.37 (broad s, $\left.1 \mathrm{H}, \mathrm{NH}_{2}\right), 8.41(\mathrm{~d}, J=8.1 \mathrm{~Hz}, 1 \mathrm{H}$, $\mathrm{Ar}), 8.56(\mathrm{~d}, J=5.5 \mathrm{~Hz}, 1 \mathrm{H}, \mathrm{Ar}), 10.30(\mathrm{~s}, 1 \mathrm{H}, \mathrm{NH}) .{ }^{13} \mathrm{C} \mathrm{NMR}(75.5 \mathrm{MHz}$, DMSO-d $d_{6}$ ), $\delta$ ppm: $12.12\left(\mathrm{CH}_{3}\right), 120.9$ (C, Ar), 123.9 (C, Ar), 136.5 (C, Ar), $148.1(\mathrm{C}=\mathrm{N}), 154.6(\mathrm{C}, \mathrm{Ar}), 179.1(\mathrm{C}=\mathrm{S})$; Anal. Calcd for $\mathrm{C}_{8} \mathrm{H}_{10} \mathrm{~N}_{4} \mathrm{~S}$ : C, 49.46; H, 5.19; N, 28.84; S, 16.51; found: C, 49.42; $\mathrm{H}$, 5.21; N, 28.79; S, 16.56. HR-MS (ESI): $195.0682[\mathrm{M}+\mathrm{H}]^{+}$.

\subsection{General procedure for the synthesis of (3-26). Example for compound (3)}

2-(Pyridin-2-ylmethylene)hydrazinecarbothioamide (2a) (0.5 g, $2.78 \mathrm{mmol})$ was dissolved in 2-propanol $(10 \mathrm{~mL})$ and then the appropriate 2-bromoacetophenone (see Scheme 1) (0.79 g, $3.05 \mathrm{mmol})$ and calcium carbonate $(0.42 \mathrm{~g}, 3.05 \mathrm{mmol})$ were added to a glass tube. The tube was placed in an ultrasonic bath $(40 \mathrm{MHz}$, $180 \mathrm{~V}$ ) and irradiated for $60 \mathrm{~min}$, at r.t. Hexane was added and the mixture was cooled in a freezer overnight. The precipitate was filtered off and washed with hexane then dried in a desiccator under vacuum. Additional amount of the desired compound were obtained from the filtrate after cooling. Pure products were obtained after recrystallization using the solvent system detailed below for each compound.

\subsubsection{2-(2-(Pyridin-2-ylmethylene)hydrazinyl)-4-phenyl-1,3- thiazole (3)}

Crystallization from toluene/hexane 7:3, afforded yellow crystals. Yield: 86\%, m.p. $\left({ }^{\circ} \mathrm{C}\right): 170 .{ }^{1} \mathrm{H}$ NMR (300 MHz, DMSO- $d_{6}$ ), $\delta$ ppm: 4.47 (broad s, 1H, NH), 7.31 (t, $J=7.2 \mathrm{~Hz}, 1 \mathrm{H}, \mathrm{Ar}$ ), 7.38-7.52 $(\mathrm{m}, 4 \mathrm{H}, 3 \mathrm{H}$ of $\mathrm{Ar}$ and $1 \mathrm{H}$ for $\mathrm{CH}$ of thiazole), $7.41(\mathrm{t}, J=7.3 \mathrm{~Hz}, 2 \mathrm{H}$, Ar), 7.49 (d, $J=5.7 \mathrm{~Hz}, 2 \mathrm{H}, \mathrm{Ar}), 7.86$ (d, $J=7.4 \mathrm{~Hz}, 1 \mathrm{H}, \mathrm{Ar}), 7.97$ (t, $J=9.2 \mathrm{~Hz}, 1 \mathrm{H}, \mathrm{Ar}), 8.10(\mathrm{~s}, 1 \mathrm{H}, \mathrm{CH}), 8.62(\mathrm{~d}, J=4.6 \mathrm{~Hz}, 1 \mathrm{H}, \mathrm{Ar}) .{ }^{13} \mathrm{C}$ NMR (100 MHz, DMSO- $\left.d_{6}\right), \delta$ ppm: $104.5(\mathrm{~S}-\mathrm{CH}), 120.0(\mathrm{C}, \mathrm{Ar})$, 124.0 (C, Ar), 125.5 (C, Ar), 127.6 (C, Ar), 128.7 (C, Ar), 139.2 (C, Ar), 147.7 (C, Ar), $150.6(\mathrm{C}, \mathrm{Ar}), 151.8(\mathrm{C}=\mathrm{N}), 167.5(\mathrm{~S}-\mathrm{C}=\mathrm{N}) . \mathrm{IR}(\mathrm{KBr}$, $\left.\mathrm{cm}^{-1}\right): 1553(\mathrm{C}=\mathrm{C}), 1612(\mathrm{C}=\mathrm{N}), 3066(\mathrm{~N}-\mathrm{H}) \mathrm{cm}^{-1}$. Anal. Calcd for $\mathrm{C}_{15} \mathrm{H}_{12} \mathrm{~N}_{4} \mathrm{~S}$ : C, 64.26; H, 4.31; N, 19.98; S, 11.44; Found: C, 64.22; H, 4.38; N, 20.02; S, 11.42. HR-MS (ESI): $281.0842[\mathrm{M}+\mathrm{H}]^{+}$.

\subsubsection{2-(2-(Pyridin-2-ylmethylene)hydrazinyl)-4-(4-tolyl)-1,3- thiazole (4)}

Crystallization from toluene/hexane 7:3, afforded dark red crystals, Yield: $79 \%$, m.p. $\left({ }^{\circ} \mathrm{C}\right):$ 197. $\mathrm{IR}\left(\mathrm{KBr}, \mathrm{cm}^{-1}\right): 1554(\mathrm{C}=\mathrm{N}), 1612$ $(\mathrm{C}=\mathrm{N}), 3154(\mathrm{~N}-\mathrm{H}) \mathrm{cm}^{-1} .{ }^{1} \mathrm{H}$ NMR (400 MHz, DMSO-d $), \delta \mathrm{ppm}$ : $2.32\left(\mathrm{~s}, 3 \mathrm{H}, \mathrm{CH}_{3}\right), 7.21$ (d, $\left.J=7.9 \mathrm{~Hz}, 2 \mathrm{H}, \mathrm{Ar}\right), 7.29(\mathrm{~s}, 1 \mathrm{H}, \mathrm{CH}$ of thiazole), 7.36 (t, 1H, $J=7.4 \mathrm{~Hz}, \mathrm{Ar}$ ), 7.50 (broad s, 1H, NH), 7.75 (d, $J=8.1 \mathrm{~Hz}, 2 \mathrm{H}, \mathrm{Ar}), 7.84(\mathrm{~d}, J=7.6 \mathrm{~Hz}, 1 \mathrm{H}, \mathrm{Ar}), 7.86(\mathrm{t}, J=7.6 \mathrm{~Hz}, 1 \mathrm{H}$, $\mathrm{Ar}), 8.06(\mathrm{~s}, 1 \mathrm{H}, \mathrm{CH}), 8.57(\mathrm{~d}, J=4.9 \mathrm{~Hz}, 1 \mathrm{H}, \mathrm{Ar}) .{ }^{13} \mathrm{C} \mathrm{NMR}(75.5 \mathrm{MHz}$, DMSO-d $\left.d_{6}\right), \delta$ ppm: $20.8\left(\mathrm{CH}_{3}\right), 104.0(\mathrm{~S}-\mathrm{CH}), 119.1$ (C, Ar), $123.6(\mathrm{C}$, Ar), 125.5 (C, Ar), 125.7 (C, Ar), 129.2 (C, Ar), 131.9 (C, Ar), 136.7 (C, Ar), $141.4(\mathrm{C}, \mathrm{Ar}), 149.5(\mathrm{Ar}), 153.2(\mathrm{C}=\mathrm{N}), 167.7(\mathrm{~S}-\mathrm{C}=\mathrm{N})$; Anal. 
Calcd for $\mathrm{C}_{16} \mathrm{H}_{14} \mathrm{~N}_{4} \mathrm{~S}$ : C, 65.28; H, 4.79; N, 19.03; S, 10.89; found: C, 65.26; H, 4.82; N, 19.09; S, 10.84. HR-MS (ESI): $295.0991[\mathrm{M}+\mathrm{H}]^{+}$.

\subsubsection{2-(2-(Pyridin-2-ylmethylene)hydrazinyl)-4-(4-}

bromophenyl)-1,3-thiazole (5)

Crystallization from toluene/hexane 7:3, afforded yellow crystals, Yield: $74 \%$, m.p. $\left({ }^{\circ} \mathrm{C}\right): 205$. IR $\left(\mathrm{KBr}, \mathrm{cm}^{-1}\right): 1569(\mathrm{C}=\mathrm{N}), 1574$ $(\mathrm{C}=\mathrm{N}), 3151(\mathrm{~N}-\mathrm{H}) .{ }^{1} \mathrm{H}$ NMR $\left(400 \mathrm{MHz}\right.$, DMSO- $\left.d_{6}\right), \delta \mathrm{ppm}: 3.42(\mathrm{~s}$, $1 \mathrm{H}, \mathrm{NH}), 7.29(\mathrm{~s}, 1 \mathrm{H}, \mathrm{CH}$ of thiazole $), 7.36(\mathrm{t}, J=6.6 \mathrm{~Hz}, 1 \mathrm{H}, \mathrm{Ar}), 7.45$ $(\mathrm{s}, 1 \mathrm{H}, \mathrm{CH}), 7.59(\mathrm{~d}, J=8.6 \mathrm{~Hz}, 2 \mathrm{H}, \mathrm{Ar}), 7.74(\mathrm{~d}, J=8.1 \mathrm{~Hz}, 1 \mathrm{H}, \mathrm{Ar}), 7.80$ (d, $J=8.6 \mathrm{~Hz}, 2 \mathrm{H}, \mathrm{Ar}), 7.86(\mathrm{t}, J=7.5 \mathrm{~Hz}, 1 \mathrm{H}, \mathrm{Ar}), 8.06(\mathrm{~d}, J=7.1 \mathrm{~Hz}$, $1 \mathrm{H}), 8.57(\mathrm{~d}, J=4.9 \mathrm{~Hz}, 1 \mathrm{H}) .{ }^{13} \mathrm{C}$ NMR $\left(75.5 \mathrm{MHz}\right.$, DMSO-d $\left.d_{6}\right), \delta \mathrm{ppm}$ : 105.6 (S-CH), 119.7 (C, Ar), 121.1 (C, Ar), 127.1 (C, Ar), 128.0 (C, Ar), 129.6 (C, Ar), 134.2 (C, Ar), 137.3 (C, Ar), 137.5 (C, Ar), 141.9 (C, Ar), $149.7(\mathrm{C}, \mathrm{Ar}), 153.4(\mathrm{C}=\mathrm{N}), 168.3(\mathrm{~S}-\mathrm{C}=\mathrm{N})$. Anal. Calcd for $\mathrm{C}_{15} \mathrm{H}_{11} \mathrm{BrN}_{4} \mathrm{~S}$ : $\mathrm{C}, 50.15 ; \mathrm{H}, 3.09 ; \mathrm{N}, 15.60 ; \mathrm{S}, 8.93$; found: $\mathrm{C}, 50.11 ; \mathrm{H}$, 3.06; N, 15.65; S, 8.97. HRMS (ESI): $358.9608[\mathrm{M}+\mathrm{H}]^{+}$.

4.4.4. 5-Methyl-2-(2-(pyridin-2-ylmethylene)hydrazinyl)-4-(4bromophenyl)-1,3-thiazole (6)

Crystallization from toluene/hexane 7:3, afforded yellow crystals, Yield: 58\%, m.p. $\left({ }^{\circ} \mathrm{C}\right): 202$. IR $\left(\mathrm{KBr}, \mathrm{cm}^{-1}\right): 1554(\mathrm{C}=\mathrm{N}), 1609$ $(\mathrm{C}=\mathrm{N}), 3152(\mathrm{~N}-\mathrm{H}) .{ }^{1} \mathrm{H}$ NMR $\left(300 \mathrm{MHz}, \mathrm{DMSO}-d_{6}\right), \delta \mathrm{ppm}: 2.43(\mathrm{~s}$, $\left.3 \mathrm{H}, \mathrm{CH}_{3}\right), 7.91(\mathrm{~s}, 1 \mathrm{H}, \mathrm{CH}), 7.41-7.60(\mathrm{~m}, 4 \mathrm{H}, \mathrm{Ar}), 8.03-8.58(\mathrm{~m}, 4 \mathrm{H}$, Ar), 13.05 (broad s, $1 \mathrm{H}, \mathrm{NH}) .{ }^{13} \mathrm{C}$ NMR $\left(75.5 \mathrm{MHz}\right.$, DMSO- $\left.d_{6}\right), \delta$ ppm: $12.3\left(\mathrm{CH}_{3}\right), 118.7(\mathrm{~S}-\mathrm{CH}), 119.6$ (C, Ar), 120.3 (C, Ar), 123.8 (C, Ar), 129.8 (C, Ar), 131.3 (C, Ar), 134.1 (C, Ar), 138.0 (C, Ar), 139.6 (C, Ar), 148.4 $(\mathrm{C}=\mathrm{N}), 167.0(\mathrm{~S}-\mathrm{C}=\mathrm{N})$. Anal. Calcd for $\mathrm{C}_{16} \mathrm{H}_{13} \mathrm{BrN}_{4} \mathrm{~S}: \mathrm{C}, 51.48$; H, 3.51; N, 15.01; S, 8.59; found: C, 51.53; H, 3.54; N, 15.04; S, 8.62. HRMS (ESI): $374.9846[\mathrm{M}+\mathrm{H}]^{+}$.

4.4.5. 2-(2-(Pyridin-2-ylmethylene)hydrazinyl)-4-(4-

fluorophenyl)-1,3-thiazole (7)

Crystallization from toluene/hexane 7:3, afforded yellow crystals, Yield: 78\%, m.p. $\left({ }^{\circ} \mathrm{C}\right): 228$. IR $\left(\mathrm{KBr}, \mathrm{cm}^{-1}\right): 1552(\mathrm{C}=\mathrm{N}), 1613$ $(\mathrm{C}=\mathrm{N}), 3029(\mathrm{~N}-\mathrm{H}) .{ }^{1} \mathrm{H}$ NMR $\left(400 \mathrm{MHz}, \mathrm{DMSO}-\mathrm{d}_{6}\right), \delta$ ppm: 4.92 (broad s, $1 \mathrm{H}, \mathrm{NH}), 7.25(\mathrm{t}, J=8.8 \mathrm{~Hz}, 2 \mathrm{H}, \mathrm{Ar}), 7.45(\mathrm{~s}, 1 \mathrm{H}, \mathrm{CH}$ of thiazole), 7.65 (t, $J=6.3 \mathrm{~Hz}, 1 \mathrm{H}, \mathrm{Ar}$ ), 7.90 (dd, $J=5.6,8.8 \mathrm{~Hz}, 2 \mathrm{H}, \mathrm{Ar}$ ), $8.08(\mathrm{~d}, J=8.0 \mathrm{~Hz}, 1 \mathrm{H}, \mathrm{Ar}), 8.15(\mathrm{~s}, 1 \mathrm{H}, \mathrm{CH}), 8.21(\mathrm{t}, J=7.5 \mathrm{~Hz}, 1 \mathrm{H}, \mathrm{Ar})$, $8.70(\mathrm{~d}, J=5.0 \mathrm{~Hz}, 1 \mathrm{H}, \mathrm{Ar}) .{ }^{13} \mathrm{C}$ NMR $\left(75.5 \mathrm{MHz}, \mathrm{DMSO}-d_{6}\right), \delta \mathrm{ppm}$ : 105.4 (S-CH), 115.4 (C, Ar), 115.6 (C, Ar), 122.3 (C, Ar), 125.1 (C, Ar), 127.5 (C, Ar), 127.6 (C, Ar), 130.8 (C, Ar), 133.5 (C, Ar), 143.4 (C, Ar), $143.8(\mathrm{C}=\mathrm{N}), 148.3(\mathrm{C}, \mathrm{Ar}), 149.6(\mathrm{C}, \mathrm{Ar}), 160.5(\mathrm{C}-\mathrm{F}), 162.9(\mathrm{C}-\mathrm{F})$, $167.1(\mathrm{~S}-\mathrm{C}=\mathrm{N})$. Anal. Calcd for $\mathrm{C}_{15} \mathrm{H}_{11} \mathrm{FN}_{4} \mathrm{~S}$ : C, 60.39; H, 3.72; N, 18.78; S, 10.75; found: C, 60.37; H, 3.74; N, 18.81; S, 10.77. HRMS (ESI): $299.0741[\mathrm{M}+\mathrm{H}]^{+}$.

\subsubsection{2-(2-(Pyridin-2-ylmethylene)hydrazinyl)-4-(4-} methoxyphenyl)-1,3-thiazole (8)

Crystallization from toluene/hexane 7:3, afforded orange crystals, Yield: $61 \%$, m.p. $\left({ }^{\circ} \mathrm{C}\right): 187$. IR $\left(\mathrm{KBr}, \mathrm{cm}^{-1}\right): 1587(\mathrm{C}=\mathrm{N}), 1610$ $(\mathrm{C}=\mathrm{N}), 3069(\mathrm{~N}-\mathrm{H}) .{ }^{1} \mathrm{H}$ NMR $\left(300 \mathrm{MHz}, \mathrm{DMSO}-d_{6}\right), \delta \mathrm{ppm}: 3.79(\mathrm{~s}$, $\left.3 \mathrm{H}, \mathrm{CH}_{3}\right), 6.97(\mathrm{~d}, J=8.3 \mathrm{~Hz}, 2 \mathrm{H}, \mathrm{Ar}), 7.29(\mathrm{~s}, 1 \mathrm{H}, \mathrm{CH}$ of thiazole), 7.73 $(\mathrm{t}, J=6.2 \mathrm{~Hz}, 1 \mathrm{H}, \mathrm{Ar}), 7.78(\mathrm{~d}, J=8.3 \mathrm{~Hz}, 2 \mathrm{H}, \mathrm{Ar}), 8.14(\mathrm{~d}, J=8.3 \mathrm{~Hz}$, $1 \mathrm{H}, \mathrm{Ar}), 8.17(\mathrm{~s}, 1 \mathrm{H}, \mathrm{CH}), 8.32(\mathrm{t}, J=7.8 \mathrm{~Hz}, 1 \mathrm{H}, \mathrm{Ar}), 8.72(\mathrm{~d}, J=4.8 \mathrm{~Hz}$, $1 \mathrm{H}, \mathrm{Ar}), 12.15$ (broad $\mathrm{s}, 1 \mathrm{H}, \mathrm{NH}) .{ }^{13} \mathrm{C}$ NMR $\left(75.5 \mathrm{MHz}\right.$, DMSO-d $d_{6}$, $\delta$ ppm: $55.2\left(\mathrm{CH}_{3}\right), 103.3(\mathrm{~S}-\mathrm{CH}), 114.1(\mathrm{C}, \mathrm{Ar}), 122.1(\mathrm{C}, \mathrm{Ar}), 124.9(\mathrm{C}$, Ar), 126.9 (C, Ar), 134.3 (C, Ar), 143.2 (C, Ar), 144.1 (C, Ar), 148.8 (C, $\mathrm{Ar}), 150.4(\mathrm{C}=\mathrm{N}), 167.1(\mathrm{~S}-\mathrm{C}=\mathrm{N})$. Anal. Calcd for $\mathrm{C}_{16} \mathrm{H}_{14} \mathrm{~N}_{4} \mathrm{OS}$ : $\mathrm{C}$, 61.92; H, 4.55; N, 18.05; S, 10.33; found: C, 61.90; H, 4.57; N, 18.08; S, 10.34. HRMS (ESI): $311.0928[\mathrm{M}+\mathrm{H}]^{+}$.
4.4.7. 2-(2-(Pyridin-2-ylmethylene)hydrazinyl)-4-(4-

chlorophenyl)-1,3-thiazole (9)

Crystallization from toluene/hexane 7:3, afforded yellow crystals, Yield: $74 \%$, m.p. $\left({ }^{\circ} \mathrm{C}\right): 226$. IR $\left(\mathrm{KBr}, \mathrm{cm}^{-1}\right): 1552(\mathrm{C}=\mathrm{N}), 1612$ $(\mathrm{C}=\mathrm{N}), 3030(\mathrm{~N}-\mathrm{H}) .{ }^{1} \mathrm{H}$ NMR (400 MHz, DMSO-d $), \delta$ ppm: $7.48(\mathrm{~d}$, $J=8.3 \mathrm{~Hz}, 2 \mathrm{H}, \mathrm{Ar}), 7.75(\mathrm{t}, J=6.1 \mathrm{~Hz}, 1 \mathrm{H}, \mathrm{Ar}), 7.56(\mathrm{~s}, 1 \mathrm{H}, \mathrm{CH}$ of thiazole), 7.88 (d, $J=8.2 \mathrm{~Hz}, 2 \mathrm{H}, \mathrm{Ar}), 8.16(\mathrm{~d}, J=8.1 \mathrm{~Hz}, 1 \mathrm{H}, \mathrm{Ar}), 8.20$ $(\mathrm{s}, 1 \mathrm{H}, \mathrm{CH}), 8.33(\mathrm{t}, J=7.6 \mathrm{~Hz}, 1 \mathrm{H}, \mathrm{Ar}), 8.43($ broad s, $1 \mathrm{H}, \mathrm{NH}), 8.75(\mathrm{~d}$, $J=4.6 \mathrm{~Hz}, 1 \mathrm{H}, \mathrm{Ar}) .{ }^{13} \mathrm{C}$ NMR $\left(75.5 \mathrm{MHz}\right.$, DMSO-d $\left.d_{6}\right), \delta \mathrm{ppm}: 105.1$ (S-CH), 119.4 (C, Ar), 123.7 (C, Ar), 127.2 (C, Ar), 128.6 (C, Ar), 132.0 (C, Ar), 133.4 (C, Ar), 137.2 (C, Ar), 141.2 (C, Ar), 149.1 (C, Ar), 149.4 (C, Ar), $152.8(\mathrm{C}=\mathrm{N}), 167.8(\mathrm{~S}-\mathrm{C}=\mathrm{N})$. Anal. Calcd for $\mathrm{C}_{15} \mathrm{H}_{11} \mathrm{ClN}_{4} \mathrm{~S}: \mathrm{C}$, 57.23; H, 3.52; N, 17.80; S, 10.19; found: C, 57.24; H, 3.51; N, 17.82; S, 10.18. HR-MS (ESI): $315.0441[\mathrm{M}+\mathrm{H}]^{+}$.

\subsubsection{2-(2-(Pyridin-2-ylmethylene)hydrazinyl)-4-(2,4- dichlorophenyl)-1,3-thiazole (10)}

Crystallization from toluene/hexane 7:3, afforded yellow crystals, Yield: 68\%, m.p. $\left({ }^{\circ} \mathrm{C}\right): 211$. IR $\left(\mathrm{KBr}, \mathrm{cm}^{-1}\right): 1551(\mathrm{C}=\mathrm{N}), 1615$ $(\mathrm{C}=\mathrm{N}), 3058(\mathrm{~N}-\mathrm{H}) .{ }^{1} \mathrm{H}$ NMR $\left(300 \mathrm{MHz}, \mathrm{DMSO}-d_{6}\right), \delta \mathrm{ppm}$ : 7.52-7.91 (m, 5H, Ar), 8.15-8.82 (m, 4H, Ar), 12.18 (s, 1H, NH). ${ }^{13} \mathrm{C}$ NMR (75.5 MHz, DMSO- $d_{6}$ ), $\delta$ ppm: $111.3(\mathrm{~S}-\mathrm{CH}), 121.9(\mathrm{C}, \mathrm{Ar}), 125.3$ (C, Ar), 126.3 (C, Ar), 128.1 (C, Ar), 130.2 (C, Ar), 132.1 (C, Ar), 132.7 (C, Ar), 135.8 (C, Ar), 142.6 (C, Ar), 144.2 (C, Ar), 146.5 (C, Ar), 149.8 (C= $\mathrm{N}), 166.9(\mathrm{~S}-\mathrm{C}=\mathrm{N})$. Anal. Calcd for $\mathrm{C}_{15} \mathrm{H}_{10} \mathrm{Cl}_{2} \mathrm{~N}_{4} \mathrm{~S}$ : C, 51.59; H, 2.89; N, 16.04; S, 9.18; found: C, 51.57; H, 2.86; N, 16.03; S, 9.15. HR-MS (ESI): $349.0144[\mathrm{M}+\mathrm{H}]^{+}$.

\subsubsection{2-(2-(Pyridin-2-ylmethylene)hydrazinyl)-4-(3,4-} dichlorophenyl)-1,3-thiazole (11)

Crystallization from toluene/hexane 7:3, afforded yellow crystals, Yield: 59\%, m.p. $\left({ }^{\circ} \mathrm{C}\right): 217$. IR $\left(\mathrm{KBr}, \mathrm{cm}^{-1}\right): 1563(\mathrm{C}=\mathrm{N}), 1614$ $(\mathrm{C}=\mathrm{N}), 3154(\mathrm{~N}-\mathrm{H}) .{ }^{1} \mathrm{H}$ NMR (400 MHz, DMSO- $\left.d_{6}\right), \delta \mathrm{ppm}: 5.22$ (broad s, $1 \mathrm{H}, \mathrm{NH}), 7.54-7.88(\mathrm{~m}, 5 \mathrm{H}, \mathrm{Ar}), 8.15-8.71(\mathrm{~m}, 4 \mathrm{H}, \mathrm{Ar}) .{ }^{13} \mathrm{C}$ NMR (100 MHz, DMSO-d $\left.d_{6}\right), \delta$ ppm: $110.9(\mathrm{~S}-\mathrm{CH}), 121.6$ (C, Ar), 124.9 (C, Ar), 127.5 (C, Ar), 129.7 (C, Ar), 131.7 (C-Cl), 132.2 (C, Ar), 132.7 (C-Cl), 134.6 (C, Ar), 142.7 (C, Ar), 143.9 (C, Ar), 146.0 (C, Ar), 149.0 $(\mathrm{C}=\mathrm{N}), 166.4(\mathrm{~S}-\mathrm{C}=\mathrm{N})$. Anal. Calcd for $\mathrm{C}_{15} \mathrm{H}_{10} \mathrm{Cl}_{2} \mathrm{~N}_{4} \mathrm{~S}: \mathrm{C}, 51.59 ; \mathrm{H}$, 2.89; N, 16.04; S, 9.18; found: C, 51.62; H, 2.85; N, 16.07; S, 9.20. HRMS (ESI): $349.0068[\mathrm{M}+\mathrm{H}]^{+}$.

\subsubsection{2-(2-(Pyridin-2-ylmethylene)hydrazinyl)-4-(3-}

nitrophenyl)-1,3-thiazole (12)

Crystallization from toluene/hexane 7:3, afforded orange crystals, Yield: $31 \%$, m.p. $\left({ }^{\circ} \mathrm{C}\right): 226$. IR $\left(\mathrm{KBr}, \mathrm{cm}^{-1}\right): 1355\left(\mathrm{NO}_{2}\right), 1560(\mathrm{C}=$ $\mathrm{N}), 1596(\mathrm{C}=\mathrm{N}), 3413(\mathrm{~N}-\mathrm{H}) .4 .45$ (broad s, 1H, NH), $7.67(\mathrm{t}$, $J=6.5 \mathrm{~Hz}, 1 \mathrm{H}, \mathrm{Ar}), 7.72(\mathrm{t}, J=8.1 \mathrm{~Hz}, 1 \mathrm{H}, \mathrm{Ar}), 7.81(\mathrm{~s}, 1 \mathrm{H}, \mathrm{CH}$ of thiazole), $8.12(\mathrm{~d}, J=8.0 \mathrm{~Hz}, 1 \mathrm{H}, \mathrm{Ar}), 8.16(\mathrm{~s}, 1 \mathrm{H}, \mathrm{CH}), 8.26(\mathrm{t}$, $J=7.9 \mathrm{~Hz}, 1 \mathrm{H}, \mathrm{Ar}), 8.31$ (d, $J=7.9 \mathrm{~Hz}, 1 \mathrm{H}, \mathrm{Ar}), 8.67(\mathrm{~s}, 1 \mathrm{H}, \mathrm{Ar}), 8.72(\mathrm{~d}$, $J=4.8 \mathrm{~Hz}, 1 \mathrm{H}, \mathrm{Ar}) .{ }^{13} \mathrm{C}$ NMR $\left(75.5 \mathrm{MHz}, \mathrm{DMSO}-d_{6}\right), \delta \mathrm{ppm:} 108.1$ (S-CH), 119.9 (C, Ar), 121.9 (C, Ar), 125.0 (C, Ar), 130.3 (C, Ar), 131.6 (C, Ar), 135.0 (C, Ar), 135.7 (C, Ar), 142.8 (C, Ar), 144.4 (C, Ar), 148.2 (C, Ar), $148.8\left(\mathrm{C}-\mathrm{NO}_{2}\right), 167.4(\mathrm{C}=\mathrm{N})$. Anal. Calcd for $\mathrm{C}_{15} \mathrm{H}_{11} \mathrm{~N}_{5} \mathrm{O}_{2} \mathrm{~S}: \mathrm{C}$, 55.38; H, 3.41; N, 21.53; S, 9.86; found: C, 55.41; H, 3.39; N, 21.56; S, 9.88. HRMS (ESI): $326.0680[\mathrm{M}+\mathrm{H}]^{+}$.

\subsubsection{2-(2-(Pyridin-2-ylmethylene)hydrazinyl)-4-(4-nitrophenyl)-} 1,3-thiazole (13)

Crystallization from toluene/hexane $7: 3$, afforded orange crystals, Yield: $42 \%$, m.p. $\left({ }^{\circ} \mathrm{C}\right): 220$. IR $\left(\mathrm{KBr}, \mathrm{cm}^{-1}\right): 1338\left(\mathrm{NO}_{2}\right), 1539(\mathrm{C}=$ C), $1598(\mathrm{C}=\mathrm{N}), 3148(\mathrm{~N}-\mathrm{H}) .{ }^{1} \mathrm{H}$ NMR $\left(300 \mathrm{MHz}, \mathrm{DMSO}-d_{6}\right), \delta \mathrm{ppm}$ : 4.74 (broad s, 1H, NH), $7.21(\mathrm{t}, J=6.1 \mathrm{~Hz}, 1 \mathrm{H}, \mathrm{Ar}), 7.50(\mathrm{~s}, 1 \mathrm{H}, \mathrm{CH}$ of thiazole), 7.74 (t, $J=7.9 \mathrm{~Hz}, 1 \mathrm{H}, \mathrm{Ar}), 7.83(\mathrm{~d}, J=8.0 \mathrm{~Hz}, 2 \mathrm{H}, \mathrm{Ar}), 7.98$ $(\mathrm{s}, 1 \mathrm{H}, \mathrm{CH}), 8.07$ (d, $J=9.0 \mathrm{~Hz}, 2 \mathrm{H}, \mathrm{Ar}), 8.22$ (d, $J=9.1 \mathrm{~Hz}, 2 \mathrm{H}, \mathrm{Ar})$, $8.47(\mathrm{~d}, J=4.9 \mathrm{~Hz}, 1 \mathrm{H}, \mathrm{Ar}) .{ }^{13} \mathrm{C}$ NMR $\left(75.5 \mathrm{MHz}, \mathrm{DMSO}-d_{6}\right), \delta \mathrm{ppm}$ : 
110.0 (S-CH), 121.6 (C, Ar), 124.1 (C, Ar), 124.8 (C, Ar), 125.7 (C, Ar), 126.4 (C, Ar), 135.9 (C, Ar), $140.2\left(\mathrm{CH}_{2}\right), 142.1$ (C, Ar), 145.0 (C, Ar), 146.3 (C, Ar), $148.6(\mathrm{C}, \mathrm{Ar}), 149.3\left(\mathrm{C}-\mathrm{NO}_{2}\right), 167.6(\mathrm{C}=\mathrm{N}) 168.9(\mathrm{~S}-\mathrm{C}=$ N). Anal. Calcd for $\mathrm{C}_{15} \mathrm{H}_{11} \mathrm{~N}_{5} \mathrm{O}_{2} \mathrm{~S}: \mathrm{C}, 55.38 ; \mathrm{H}, 3.41 ; \mathrm{N}, 21.53 ; \mathrm{S}, 9.86$; found: C, 55.41; H, 3.46; N, 21.56; S, 9.88. HRMS (ESI): 326.0696 $[\mathrm{M}+\mathrm{H}]^{+}$.

4.4.12. 2-(2-(Pyridin-2-ylmethylene)hydrazinyl)-4-(naphthalen-1yl)-1,3-thiazole (14)

Crystallization from toluene/hexane $7: 3$, afforded brown crystals, Yield: $87 \%$, m.p. $\left({ }^{\circ} \mathrm{C}\right): 216$. IR $\left(\mathrm{KBr}, \mathrm{cm}^{-1}\right): 1540(\mathrm{C}=\mathrm{N}), 1602$ $(\mathrm{C}=\mathrm{N}), 3112(\mathrm{~N}-\mathrm{H}) .{ }^{1} \mathrm{H}$ NMR $\left(400 \mathrm{MHz}, \mathrm{DMSO}-d_{6}\right), \delta \mathrm{ppm}: 7.31(\mathrm{t}$, $J=6.0 \mathrm{~Hz}, 1 \mathrm{H}, \mathrm{Ar}), 7.45(\mathrm{~s}, 1 \mathrm{H}, \mathrm{CH}$ of thiazole), $7.49(\mathrm{~d}, J=7.6 \mathrm{~Hz}, 2 \mathrm{H}$, Ar), $7.82(\mathrm{t}, J=7.4 \mathrm{~Hz}, 1 \mathrm{H}, \mathrm{Ar}), 7.94-7.85(\mathrm{~m}, 5 \mathrm{H}, \mathrm{Ar}), 8.00(\mathrm{~d}$, $J=8.6 \mathrm{~Hz}, 1 \mathrm{H}, \mathrm{Ar}), 8.07(\mathrm{~s}, 1 \mathrm{H}, \mathrm{CH}), 8.37$ (broad s, $1 \mathrm{H}, \mathrm{NH}), 8.54$ (d, $J=4.9 \mathrm{~Hz}, 1 \mathrm{H}, \mathrm{Ar}) .{ }^{13} \mathrm{C}$ NMR $\left(75.5 \mathrm{MHz}\right.$, DMSO-d $\left.d_{6}\right), \delta \mathrm{ppm:} 106.5$ (S-CH), 122.5 (C, Ar), 123.8 (C, Ar), 124.2 (C, Ar), 125.2 (C, Ar), 126.1 (C, Ar), 126.4 (C, Ar), 127.5 (C, Ar), 128.1 (C, Ar), 128.2 (C, Ar), 131.5 (C, Ar), 132.5 (C, Ar), 132.7 (C, Ar), 133.0 (C, Ar), $142.8\left(\mathrm{CH}_{2}\right), 144.4$ (C, Ar), $147.7(C, A r), 150.5(C=N), 167.0(S-C=N)$. Anal. Calcd for $\mathrm{C}_{19} \mathrm{H}_{14} \mathrm{~N}_{4} \mathrm{~S}$ : C, 69.07; $\mathrm{H}, 4.27$; N, 16.96; S, 9.70; found: C, 69.09; $\mathrm{H}$, 4.24; N, 16.94; S, 9.73. HRMS (ESI): $331.1007[\mathrm{M}+\mathrm{H}]^{+}$.

\subsubsection{3. (2-(1-(Pyridin-2-yl)ethylene)hydrazinyl)-4-phenyl-1,3-} thiazole (15)

Crystallization from toluene/hexane 7:3, afforded yellow crystals, Yield: 79\%; m.p. $\left({ }^{\circ} \mathrm{C}\right): 151$. IR $\left(\mathrm{KBr}, \mathrm{cm}^{-1}\right): 1575(\mathrm{C}=\mathrm{N}), 1615$ $(\mathrm{C}=\mathrm{N}), 3058(\mathrm{~N}-\mathrm{H}) .{ }^{1} \mathrm{H}$ NMR $(400 \mathrm{MHz}$, DMSO-d 6 ), $\delta$ ppm: 2.43 (s, $3 \mathrm{H}, \mathrm{CH}_{3}$ ), 5.53 (broad s, $1 \mathrm{H}, \mathrm{NH}$ ), 7.30 (t, J=7.4 Hz, 1H, Ar), 7.39 (t, $J=7.4 \mathrm{~Hz}, 2 \mathrm{H}, \mathrm{Ar}), 7.44(\mathrm{~s}, 1 \mathrm{H}, \mathrm{CH}$ of thiazole), $7.76(\mathrm{t}, J=6.5 \mathrm{~Hz}, 1 \mathrm{H}$, Ar), $7.85(\mathrm{~d}, J=7.6 \mathrm{~Hz}, 2 \mathrm{H}, \mathrm{Ar}), 8.23(\mathrm{~d}, J=8.3 \mathrm{~Hz}, 1 \mathrm{H}, \mathrm{Ar}), 8.35$ (t, $J=8.0 \mathrm{~Hz}, 1 \mathrm{H}, \mathrm{Ar}), 8.73(\mathrm{~d}, J=5.5 \mathrm{~Hz}, 1 \mathrm{H}, \mathrm{Ar}) .{ }^{13} \mathrm{C} \mathrm{NMR}(75.5 \mathrm{MHz}$, DMSO- $\left.d_{6}\right), \delta$ ppm: $13.4\left(\mathrm{CH}_{3}\right), 105.9(\mathrm{~S}-\mathrm{CH}), 123.6(\mathrm{C}, \mathrm{Ar}), 125.6(\mathrm{C}$, Ar), 126.0 (C, Ar), 128.4 (C, Ar), 129.2 (C, Ar), 134.2 (C, Ar), 141.0 (C, Ar), 143.9 (C, Ar), 144.6 (C, Ar), 147.5 (C, Ar), $150.0(\mathrm{C}=\mathrm{N}), 168.9$ $(\mathrm{S}-\mathrm{C}=\mathrm{N})$. Anal. Calcd for $\mathrm{C}_{16} \mathrm{H}_{14} \mathrm{~N}_{4} \mathrm{~S}$ : C, 65.28; H, 4.79; N, 19.03; , 10.89; found: C, 65.31; H, 4.82; N, 19.06; S, 10.87. HRMS (ESI): $295.0985[\mathrm{M}+\mathrm{H}]^{+}$.

\subsubsection{4. (2-(1-(Pyridin-2-yl)ethylene)hydrazinyl)-4-(4-tolyl)-1,3-} thiazole (16)

Crystallization from toluene/hexane 7:3, afforded yellow crystals, Yield: $68 \%$, m.p. $\left({ }^{\circ} \mathrm{C}\right): 143$. IR $\left(\mathrm{KBr}, \mathrm{cm}^{-1}\right): 1496(\mathrm{C}=\mathrm{N}), 1613$ $(\mathrm{C}=\mathrm{N}), 3058(\mathrm{~N}-\mathrm{H}) .{ }^{1} \mathrm{H}$ NMR $\left(300 \mathrm{MHz}, \mathrm{DMSO}-\mathrm{d}_{6}\right), \delta \mathrm{ppm}: 2.31(\mathrm{~s}$, $\left.3 \mathrm{H}, \mathrm{CH}_{3}\right), 2.39\left(\mathrm{~s}, 3 \mathrm{H}, \mathrm{CH}_{3}\right), 3.84($ broad s, $1 \mathrm{H}, \mathrm{NH}), 7.21(\mathrm{~d}, J=8.0 \mathrm{~Hz}$, $2 \mathrm{H}, \mathrm{Ar}), 7.28(\mathrm{~s}, 1 \mathrm{H}, \mathrm{CH}$ of thiazole $), 7.35(\mathrm{t}, J=6.1 \mathrm{~Hz}, 1 \mathrm{H}, \mathrm{Ar}), 7.76(\mathrm{~d}$, $J=8.1 \mathrm{~Hz}, 2 \mathrm{H}, \mathrm{Ar}), 7.83(\mathrm{t}, J=7.8 \mathrm{~Hz}, 1 \mathrm{H}, \mathrm{Ar}), 8.02(\mathrm{~d}, J=8.1 \mathrm{~Hz}, 1 \mathrm{H}$, $\mathrm{Ar}), 8.57(\mathrm{~d}, J=4.2 \mathrm{~Hz}, 1 \mathrm{H}, \mathrm{Ar}) .{ }^{13} \mathrm{C}$ NMR $\left(75.5 \mathrm{MHz}\right.$, DMSO- $\left.d_{6}\right): 12.7$ $\left(\mathrm{CH}_{3}\right), 20.7\left(\mathrm{CH}_{3}\right), 103.9(\mathrm{~S}-\mathrm{CH}), 121.7$ (C, Ar), 124.4 (C, Ar), 125.8 (C, Ar), 129.1 (C, Ar), 136.9 (C, Ar), 141.0 (C, Ar), 143.6 (C, Ar), 145.3 (C, Ar), $148.3(\mathrm{Ar}), 151.7(\mathrm{C}=\mathrm{N}), 168.9(\mathrm{~S}-\mathrm{C}=\mathrm{N})$. Anal. Calcd for $\mathrm{C}_{17} \mathrm{H}_{16} \mathrm{~N}_{4} \mathrm{~S}$ : C, 66.21; H, 5.23; N, 18.17; S, 10.40; found: C, 66.26; $\mathrm{H}$, 5.26; N, 18.18; S, 10.39. HR-MS (ESI): $309.7527[\mathrm{M}+\mathrm{H}]^{+}$.

\subsubsection{5. (2-(1-(Pyridin-2-yl)ethylene)hydrazinyl)-4-(4-} bromophenyl)-1,3-thiazole (17)

Crystallization from toluene/hexane 7:3, afforded yellow crystals, Yield: $61 \%$ m.p. $\left({ }^{\circ} \mathrm{C}\right): 202$. IR $\left(\mathrm{KBr}, \mathrm{cm}^{-1}\right): 1567(\mathrm{C}=\mathrm{N}), 1615$ $(\mathrm{C}=\mathrm{N}), 3029(\mathrm{~N}-\mathrm{H}) .{ }^{1} \mathrm{H}$ NMR $\left(400 \mathrm{MHz}, \mathrm{DMSO}-\mathrm{d}_{6}\right), \delta \mathrm{ppm}: 2.39(\mathrm{~s}$, $\left.3 \mathrm{H}, \mathrm{CH}_{3}\right), 7.36(\mathrm{t}, J=6.3 \mathrm{~Hz}, 1 \mathrm{H}, \mathrm{Ar}), 7.45(\mathrm{~s}, 1 \mathrm{H}, \mathrm{CH}$ of thiazole $), 7.60$ $(\mathrm{d}, J=8.6 \mathrm{~Hz}, 2 \mathrm{H}, \mathrm{Ar}), 7.87-7.81(\mathrm{~m}, 4 \mathrm{H}, \mathrm{Ar}), 8.02(\mathrm{~d}, J=8.1 \mathrm{~Hz}, 1 \mathrm{H}$, $\mathrm{Ar}), 8.57(\mathrm{~d}, J=4.8 \mathrm{~Hz}, 1 \mathrm{H}, \mathrm{Ar}), 10.33$ (broad s, $1 \mathrm{H}, \mathrm{NH}) .{ }^{13} \mathrm{C} \mathrm{NMR}$ (75.5 MHz, DMSO-d $), \delta$ ppm: $12.7\left(\mathrm{CH}_{3}\right), 105.8(\mathrm{~S}-\mathrm{CH}), 120.0(\mathrm{C}$, Ar), 121.0 (C, Ar), 123.9 (C, Ar), 127.4 (C, Ar), 128.0 (C, Ar), 132.0 (C, Ar), 134.4 (C, Ar), 137.1 (C, Ar), 147.6 (C, Ar), 149.0 (C, Ar), 155.3 (C=
$\mathrm{N}), 170.0(\mathrm{~S}-\mathrm{C}=\mathrm{N})$. Anal. Calcd for $\mathrm{C}_{16} \mathrm{H}_{13} \mathrm{BrN}_{4} \mathrm{~S}$ : C, 51.48; H, 3.51; N, 15.01; S, 8.59; found: C, 51.51; H, 3.54; N, 15.04; S, 8.56. HRMS (ESI): $373.8177[\mathrm{M}+\mathrm{H}]^{+}$.

\subsubsection{5-Methyl-(2-(1-(pyridin-2-yl)ethylene)hydrazinyl)-4-(4-} bromophenyl)-1,3-thiazole (18)

Crystallization from toluene/hexane 7:3, afforded yellow crystals, Yield: 52\%, m.p. $\left({ }^{\circ} \mathrm{C}\right): 198$. IR $\left(\mathrm{KBr}, \mathrm{cm}^{-1}\right): 1565(\mathrm{C}=\mathrm{N}), 1604$ $(\mathrm{C}=\mathrm{N}), 3164(\mathrm{~N}-\mathrm{H}) .{ }^{1} \mathrm{H}$ NMR $\left(300 \mathrm{MHz}, \mathrm{DMSO}-d_{6}\right), \delta \mathrm{ppm}: 2.33$ (s, $\left.3 \mathrm{H}, \mathrm{CH}_{3}\right), 2.40\left(\mathrm{~s}, 3 \mathrm{H}, \mathrm{CH}_{3}\right), 7.28(\mathrm{t}, J=6.0 \mathrm{~Hz}, 1 \mathrm{H}, \mathrm{Ar}), 7.60-7.57(\mathrm{~m}$, $4 \mathrm{H}, \mathrm{Ar}), 7.77(\mathrm{t}, J=7.7 \mathrm{~Hz}, 1 \mathrm{H}, \mathrm{Ar}), 7.99(\mathrm{~d}, J=8.0 \mathrm{~Hz}, 1 \mathrm{H}, \mathrm{Ar}), 8.52(\mathrm{~d}$, $J=4.0 \mathrm{~Hz}, 1 \mathrm{H}, \mathrm{Ar}), 8.81$ (broad s, $1 \mathrm{H}, \mathrm{NH}) .{ }^{13} \mathrm{C} \mathrm{NMR}(75.5 \mathrm{MHz}$, DMSO- $\left.d_{6}\right), \delta$ ppm: $12.6\left(\mathrm{CH}_{3}\right), 12.7\left(\mathrm{CH}_{3}\right), 119.0(\mathrm{~S}-\mathrm{CH}), 119.9(\mathrm{C}, \mathrm{Ar})$, 120.6 (C, Ar), 123.7 (C, Ar), 130.3 (C, Ar), 131.7 (C, Ar), 134.8 (C, Ar), $136.9(\mathrm{C}, \mathrm{Ar}), 155.4(\mathrm{C}, \mathrm{Ar}), 149.0(\mathrm{C}=\mathrm{N}), 166.0(\mathrm{~S}-\mathrm{C}=\mathrm{N})$. Anal. Calcd for $\mathrm{C}_{17} \mathrm{H}_{15} \mathrm{BrN}_{4} \mathrm{~S}$ : C, 52.72; H, 3.90; N, 14.47; S, 8.28; found: C, 52.75; $\mathrm{H}, 3.94 ; \mathrm{N}, 14.45 ; \mathrm{S}, 8.26$. HRMS (ESI): $387.8449[\mathrm{M}+\mathrm{H}]^{+}$.

\subsubsection{7. (2-(1-(Pyridin-2-yl)ethylene)hydrazinyl)-4-(4-} fluorophenyl)-1,3-thiazole (19)

Crystallization from toluene/hexane 7:3, afforded yellow crystals, Yield: $73 \%$, m.p. $\left({ }^{\circ} \mathrm{C}\right): 209$. IR $\left(\mathrm{KBr}, \mathrm{cm}^{-1}\right): 1560(\mathrm{C}=\mathrm{N}), 3060$ $(\mathrm{N}-\mathrm{H}) .{ }^{1} \mathrm{H}$ NMR $\left(300 \mathrm{MHz}, \mathrm{DMSO}-d_{6}\right), \delta \mathrm{ppm}: 2.42\left(\mathrm{~s}, 3 \mathrm{H}, \mathrm{CH}_{3}\right), 6.07$ (broad s, $1 \mathrm{H}, \mathrm{NH}), 7.25$ (d, $J=8.6,5.6 \mathrm{~Hz}, 2 \mathrm{H}, \mathrm{Ar}), 7.40(\mathrm{~s}, 1 \mathrm{H}, \mathrm{CH}$ of thiazole), 7.57 (t, $J=5.0 \mathrm{~Hz}, 1 \mathrm{H}, \mathrm{Ar}$ ), 7.91 (dd, $J=8.6,5.6 \mathrm{~Hz}, 2 \mathrm{H}, \mathrm{Ar}$ ), $8.12(\mathrm{~d}, J=8.0 \mathrm{~Hz}, 1 \mathrm{H}, \mathrm{Ar}), 8.13(\mathrm{t}, J=7.2 \mathrm{~Hz}, 1 \mathrm{H}, \mathrm{Ar}), 8.65(\mathrm{~d}$, $J=5.0 \mathrm{~Hz}, 1 \mathrm{H}, \mathrm{Ar}) .{ }^{13} \mathrm{C}$ NMR $\left(75.5 \mathrm{MHz}, \mathrm{DMSO}-d_{6}\right), \delta \mathrm{ppm}: 12.4$ $\left(\mathrm{CH}_{3}\right), 104.4(\mathrm{~S}-\mathrm{CH}), 115.4$ (C, Ar), 120.2 (C, Ar), 123.7 (C, Ar), 127.5 (C, Ar), 131.2 (C, Ar), 137.8 (C, Ar), 146.0 (C, Ar), 147.7 (C, Ar), 154.0 (C, $\mathrm{Ar}), 160.0(\mathrm{C}=\mathrm{N}), 169.3(\mathrm{~S}-\mathrm{C}=\mathrm{N})$. Anal. Calcd for $\mathrm{C}_{16} \mathrm{H}_{13} \mathrm{FN}_{4} \mathrm{~S}$ : $\mathrm{C}$, 61.52; H, 4.19; N, 17.94; S, 10.27; found: C, 61.57; H, 4.21; N, 17.95; S, 10.30. HRMS (ESI): $[\mathrm{M}+\mathrm{H}]^{+}$.

\subsubsection{8. (2-(1-(Pyridin-2-yl)ethylene)hydrazinyl)-4-(4-} methoxyphenyl)-1,3-thiazole (20)

Crystallization from toluene/hexane 7:3, afforded orange crystals, Yield: 58\%, m.p. $\left({ }^{\circ} \mathrm{C}\right): 216$. IR $\left(\mathrm{KBr}, \mathrm{cm}^{-1}\right): 1496(\mathrm{C}=\mathrm{C}), 1610$ $(\mathrm{C}=\mathrm{N}), 3359(\mathrm{~N}-\mathrm{H}) .{ }^{1} \mathrm{H}$ NMR $\left(300 \mathrm{MHz}, \mathrm{DMSO}-d_{6}\right), \delta \mathrm{ppm}: 2.42(\mathrm{~s}$, $\left.3 \mathrm{H}, \mathrm{CH}_{3}\right), 3.78\left(\mathrm{~s}, 3 \mathrm{H}, \mathrm{CH}_{3}\right), 7.25(\mathrm{~s}, 1 \mathrm{H}, \mathrm{S}-\mathrm{CH}), 6.98-7.93(\mathrm{~m}, 4 \mathrm{H}, \mathrm{Ar})$, 8.19-8.83 (m, 4H, Ar), 10.90 (broad s, $1 \mathrm{H}, \mathrm{NH}) .{ }^{13} \mathrm{C} \mathrm{NMR} \mathrm{(75.5} \mathrm{MHz,}$ DMSO- $\left.d_{6}\right), \delta$ ppm: $12.7\left(\mathrm{CH}_{3}\right), 55.1\left(\mathrm{CH}_{3}\right), 102.7(\mathrm{~S}-\mathrm{CH}), 114.0(\mathrm{C}, \mathrm{Ar})$, 121.7 (C, Ar), 124.4 (C, Ar), 124.5 (C, Ar), 125.9 (C, Ar), 126.9 (C, Ar), 143.6 (C, Ar), $145.4(\mathrm{C}, \mathrm{Ar}), 158.9(\mathrm{C}=\mathrm{N}), 169.5(\mathrm{~S}-\mathrm{C}=\mathrm{N})$. Anal. Calcd for $\mathrm{C}_{17} \mathrm{H}_{16} \mathrm{~N}_{4} \mathrm{OS}$ : C, 62.94; H, 4.97; N, 17.27; S, 9.88; found: C, 62.91; $\mathrm{H}, 4.95$; N, 17.28; S, 9.90. HR-MS (ESI): $325.0975[\mathrm{M}+\mathrm{H}]^{+}$.

\subsubsection{9. (2-(1-(Pyridin-2-yl)ethylene)hydrazinyl)-4-(4-}

\section{chlorophenyl)-1,3-thiazole (21)}

Crystallization from toluene/hexane 7:3, afforded yellow crystals, Yield: $73 \%$, m.p. $\left({ }^{\circ} \mathrm{C}\right): 222 . \mathrm{IR}\left(\mathrm{KBr}, \mathrm{cm}^{-1}\right): 1574(\mathrm{C}=\mathrm{N}), 1603$ $(\mathrm{C}=\mathrm{N}), 3359(\mathrm{~N}-\mathrm{H}) .{ }^{1} \mathrm{H}$ NMR (300 MHz, DMSO-d $), \delta$ ppm: $2.39(\mathrm{~s}$, $\left.3 \mathrm{H}, \mathrm{CH}_{3}\right), 7.35(\mathrm{t}, J=5.9 \mathrm{~Hz}, 1 \mathrm{H}, \mathrm{Ar}), 7.42(\mathrm{~s}, 1 \mathrm{H}, \mathrm{CH}$ of thiazole $), 7.46$ $(\mathrm{d}, J=8.4 \mathrm{~Hz}, 2 \mathrm{H}, \mathrm{Ar}), 7.83(\mathrm{t}, J=7.8 \mathrm{~Hz}, 1 \mathrm{H}, \mathrm{Ar}), 7.89$ (d, $J=8.4 \mathrm{~Hz}$, $2 \mathrm{H}, \mathrm{Ar}), 8.02$ (d, $J=8.0 \mathrm{~Hz}, 1 \mathrm{H}, \mathrm{Ar}), 8.56$ (d, $J=4.2 \mathrm{~Hz}, 1 \mathrm{H}, \mathrm{Ar}), 11.45$ (broad s, $1 \mathrm{H}, \mathrm{NH}) .{ }^{13} \mathrm{C}$ NMR $\left(75.5 \mathrm{MHz}\right.$, DMSO- $\left.d_{6}\right), \delta \mathrm{ppm}: 13.4\left(\mathrm{CH}_{3}\right)$, 106.5 (S-CH), 122.6 (C, Ar), 125.3 (C, Ar), 127.7 (C, Ar), 129.2 (C, Ar), 132.6 (C, Ar), 133.6 (C, Ar), 143.0 (C, Ar), 145.5 (C, Ar), $151.7(\mathrm{C}=\mathrm{N})$, $169.4(\mathrm{~S}-\mathrm{C}=\mathrm{N})$. Anal. Calcd for $\mathrm{C}_{16} \mathrm{H}_{13} \mathrm{ClN}_{4} \mathrm{~S}$ : C, 58.44; H, 3.98; N, 17.04; S, 9.75; found: C, 58.47; H, 3.95; N, 17.09; S, 9.71. HR-MS (ESI): $329.8148[\mathrm{M}+\mathrm{H}]^{+}$.

\subsubsection{0. (2-(1-(Pyridin-2-yl)ethylene)hydrazinyl)-4-(2,4-} dichlorophenyl)-1,3-thiazole (22)

Crystallization from toluene/hexane 7:3, afforded yellow crystals, Yield: 62\%, m.p. $\left({ }^{\circ} \mathrm{C}\right): 227$; IR $\left(\mathrm{KBr}, \mathrm{cm}^{-1}\right): 1521(\mathrm{C}=\mathrm{N}), 1609$ 
$(\mathrm{C}=\mathrm{N}), 3058(\mathrm{~N}-\mathrm{H}) .{ }^{1} \mathrm{H}$ NMR $\left(300 \mathrm{MHz}\right.$, DMSO- $\left.d_{6}\right), \delta \mathrm{ppm}: 2.43(\mathrm{~s}$, $\left.3 \mathrm{H}, \mathrm{CH}_{3}\right), 4.04$ (broad $\left.\mathrm{s}, 1 \mathrm{H}, \mathrm{NH}\right), 7.43(\mathrm{~s}, 1 \mathrm{H}, \mathrm{CH}$ of thiazole), 7.32-7.88 (m, 3H, Ar), 8.19-8.69 (m, 4H, Ar). ${ }^{13} \mathrm{C}$ NMR $(75.5 \mathrm{MHz}$, DMSO-d $), \delta$ ppm: $12.8\left(\mathrm{CH}_{3}\right), 105.0(\mathrm{~S}-\mathrm{CH}), 124.4(\mathrm{C}, \mathrm{Ar}), 125.5(\mathrm{C}$, Ar), 127.7 (C, Ar), 128.6 (C, Ar), 134.2 (C, Ar), 141.2 (C, Ar), 143.1 (C, Ar), $145.4(C, A r), 151.7(C=N), 169.0(S-C=N)$. Anal. Calcd for $\mathrm{C}_{16} \mathrm{H}_{12} \mathrm{Cl}_{2} \mathrm{~N}_{4} \mathrm{~S}$ : C, 52.90; H, 3.33; N, 15.42; S, 8.83; found: $\mathrm{C}, 52.93 ; \mathrm{H}$, 3.35; N, 15.47; S, 8.84. HR-MS (ESI): $362.9432[\mathrm{M}+\mathrm{H}]^{+}$.

\subsubsection{1. (2-(1-(Pyridin-2-yl)ethylene)hydrazinyl)-4-(3,4-} dichlorophenyl)-1,3-thiazole (23)

Crystallization from toluene/hexane $7: 3$, afforded yellow crystals, Yield: $69 \%$ m.p. $\left({ }^{\circ} \mathrm{C}\right): 209$. IR $\left(\mathrm{KBr}, \mathrm{cm}^{-1}\right): 1554(\mathrm{C}=\mathrm{N}), 1614$ $(\mathrm{C}=\mathrm{N}), 3061(\mathrm{~N}-\mathrm{H}) .{ }^{1} \mathrm{H}$ NMR $\left(300 \mathrm{MHz}, \mathrm{DMSO}-d_{6}\right), \delta \mathrm{ppm}: 2.43(\mathrm{~s}$, $3 \mathrm{H}, \mathrm{CH}_{3}$ ), 4.12 (broad $\left.\mathrm{s}, 1 \mathrm{H}, \mathrm{NH}\right), 7.48(\mathrm{~s}, 1 \mathrm{H}, \mathrm{CH}$ of thiazole), 7.29-7.83 (m, 3H, Ar), 8.12-8.63 (m, 4H, Ar). ${ }^{13} \mathrm{C}$ NMR $(75.5 \mathrm{MHz}$, DMSO-d $\left.d_{6}\right), \delta$ ppm: $12.8\left(\mathrm{CH}_{3}\right), 110.4(\mathrm{~S}-\mathrm{CH}), 121.3$ (C, Ar), 124.3 (C, Ar), 127.4 (C, Ar), 128.6 (C, Ar), 145.4 (C, Ar), 145.8 (C, Ar), 146.3 (C, $\mathrm{Ar}), 152.2(\mathrm{C}, \mathrm{Ar}), 158.1(\mathrm{C}=\mathrm{N}), 169.4(\mathrm{~S}-\mathrm{C}=\mathrm{N})$. Anal. Calcd for $\mathrm{C}_{16} \mathrm{H}_{12} \mathrm{Cl}_{2} \mathrm{~N}_{4} \mathrm{~S}$ : C, 52.90; H, 3.33; N, 15.42; S, 8.83; found: $\mathrm{C}, 52.89 ; \mathrm{H}$, 3.31; N, 15.43; S, 8.80. HR-MS (ESI): $363.0220[\mathrm{M}+\mathrm{H}]^{+}$.

\subsubsection{2. (2-(1-(Pyridin-2-yl)ethylene)hydrazinyl)-4-(3-} nitrophenyl)-1,3-thiazole (24)

Crystallization from toluene/hexane 7:3, afforded orange crystals, Yield: $49 \%$, m.p. $\left({ }^{\circ} \mathrm{C}\right): 229$. IR $\left(\mathrm{KBr}, \mathrm{cm}^{-1}\right): 1345\left(\mathrm{NO}_{2}\right), 1453(\mathrm{C}=$ C), $1601(\mathrm{C}=\mathrm{N}), 3054(\mathrm{~N}-\mathrm{H}) .{ }^{1} \mathrm{H}$ NMR $\left(300 \mathrm{MHz}\right.$, DMSO- $\left.d_{6}\right), \delta \mathrm{ppm}$ : 2.43 (s, 3H, CH $)_{3}, 4.11$ (bs, $\left.1 \mathrm{H}, \mathrm{NH}\right), 7.47$ (s, 1H, S-CH), 7.38-7.91 (m, $4 \mathrm{H}, \mathrm{Ar}), 8.15-8.71(\mathrm{~m}, 4 \mathrm{H}, \mathrm{Ar}) .{ }^{13} \mathrm{C}$ NMR (100 MHz, DMSO-d $)$, $\delta$ ppm: $12.8\left(\mathrm{CH}_{3}\right), 107.8$ (C, Ar), 119.9 (C, Ar), 121.7 (C, Ar), 122.1 (C, Ar), 124.5 (C, Ar), 130.2 (C, Ar), 131.5 (C, Ar), 135.9 (C, Ar), 138.6 (C, $\mathrm{Ar}), 141.1$ (C, Ar), 145.5 (C, $\mathrm{Ar}), 147.5(\mathrm{C}=\mathrm{N}), 148.2\left(\mathrm{C}-\mathrm{NO}_{2}\right), 169.0$ $(\mathrm{S}-\mathrm{C}=\mathrm{N})$. Anal. Calcd for $\mathrm{C}_{16} \mathrm{H}_{13} \mathrm{~N}_{5} \mathrm{O}_{2} \mathrm{~S}: \mathrm{C}, 56.63 ; \mathrm{H}, 3.86 ; \mathrm{N}, 20.64$; S, 9.45; found: C, 56.65; H, 3.89; N, 20.67; S, 9.48. HR-MS (ESI): $340.0851[\mathrm{M}+\mathrm{H}]^{+}$.

\subsubsection{3. (2-(1-(Pyridin-2-yl)ethylene)hydrazinyl)-4-(4-} nitrophenyl)-1,3-thiazole (25)

Crystallization from toluene/hexane $7: 3$, afforded orange crystals, Yield: 58\%, m.p. $\left({ }^{\circ} \mathrm{C}\right): 245$. IR $\left(\mathrm{KBr}, \mathrm{cm}^{-1}\right): 1577(\mathrm{C}=\mathrm{N}), 1596$ $(\mathrm{C}=\mathrm{N}), 3342(\mathrm{~N}-\mathrm{H}) .{ }^{1} \mathrm{H}$ NMR $\left(400 \mathrm{MHz}, \mathrm{DMSO}-d_{6}\right), \delta \mathrm{ppm}: 2.37(\mathrm{~s}$, $\left.3 \mathrm{H}, \mathrm{CH}_{3}\right), 7.30(\mathrm{t}, J=6.2 \mathrm{~Hz}, 1 \mathrm{H}, \mathrm{Ar}), 7.63(\mathrm{~s}, 1 \mathrm{H}, \mathrm{CH}$ of thiazole $), 7.74$ (broad s, $1 \mathrm{H}, \mathrm{NH}), 7.79(\mathrm{t}, J=7.4 \mathrm{~Hz}, 1 \mathrm{H}, \mathrm{Ar}), 8.02(\mathrm{~d}, J=8.1 \mathrm{~Hz}, 1 \mathrm{H}$, Ar), 8.10 (d, $J=9.0 \mathrm{~Hz}, 2 \mathrm{H}, \mathrm{Ar}$ ), 8.25 (d, $J=9.0 \mathrm{~Hz}, 2 \mathrm{H}, \mathrm{Ar}$ ), 8.53 (d, $J=4.8 \mathrm{~Hz}, 1 \mathrm{H}, \mathrm{Ar}) .{ }^{13} \mathrm{C}$ NMR (75.5 MHz, DMSO- $\left.d_{6}\right), \delta \mathrm{ppm:} 12.4$ $\left(\mathrm{CH}_{3}\right), 108.6(\mathrm{~S}-\mathrm{CH}), 119.4$ (C, Ar), 122.9 (C, Ar), 124.2 (C, Ar), 126.3 (C, Ar), 136.4 (C, Ar), 141.2 (C, Ar), 146.1 (C, Ar), 148.6 (C, Ar), 155.5 $(\mathrm{C}=\mathrm{N}), 172.0(\mathrm{~S}-\mathrm{C}=\mathrm{N})$. Anal. Calcd for $\mathrm{C}_{16} \mathrm{H}_{13} \mathrm{~N}_{5} \mathrm{O}_{2} \mathrm{~S}: \mathrm{C}, 56.63 ; \mathrm{H}$, 3.86; N, 20.64; S, 9.45; found: C, 56.67; H, 3.87; N, 20.65; S, 9.48. HR-MS (ESI): $340.0683[\mathrm{M}+\mathrm{H}]^{+}$.

4.4.24. (2-(1-(Pyridin-2-yl)ethylene)hydrazinyl)-4-(naphthalen-1yl)-1,3-thiazole (26)

Crystallization from toluene/hexane $7: 3$, afforded brown crystals, Yield: $89 \%$ m.p. $\left({ }^{\circ} \mathrm{C}\right): 203$. IR $\left(\mathrm{KBr}, \mathrm{cm}^{-1}\right): 1556(\mathrm{C}=\mathrm{N}), 1614$ $(\mathrm{C}=\mathrm{N}), 3035(\mathrm{~N}-\mathrm{H}) .{ }^{1} \mathrm{H}$ NMR $\left(300 \mathrm{MHz}, \mathrm{DMSO}-d_{6}\right), \delta \mathrm{ppm}: 1.70(\mathrm{~s}$, $\left.3 \mathrm{H}, \mathrm{CH}_{3}\right), 3.66$ (broad $\left.\mathrm{s}, 1 \mathrm{H}, \mathrm{NH}\right), 7.48(\mathrm{~s}, 1 \mathrm{H}, \mathrm{CH}$ of thiazole), 7.30-7.52 (m, 4H, Ar), 7.81-8.00 (m, 6H, Ar), $8.55(\mathrm{~d}, J=4.9 \mathrm{~Hz}, 1 \mathrm{H}$, Ar). ${ }^{13} \mathrm{C}$ NMR (75.5 MHz, DMSO- $\left.d_{6}\right), \delta \mathrm{ppm}: 24.0\left(\mathrm{CH}_{3}\right), 104.5$ (S-CH), 119.0 (C, Ar), 124.0 (C, Ar), 124.1 (C, Ar), 126.4 (C, Ar), 127.6 (C, Ar), 128.0 (C, Ar), 128.1 (C, Ar), 136.7 (C, Ar), 144.3 (C, Ar), 149.4 (C, Ar), $150.3(\mathrm{C}, \mathrm{Ar}), 153.7(\mathrm{C}=\mathrm{N}), 169.3(\mathrm{~S}-\mathrm{C}=\mathrm{N})$. Anal. Calcd for $\mathrm{C}_{20} \mathrm{H}_{16} \mathrm{~N}_{4} \mathrm{~S}$ : C, 69.74; H, 4.68; N, 16.27; S, 9.31; found: C, 69.70; $\mathrm{H}$ 4.70; N, 16.31; S, 9.34. HR-MS (ESI): $345.1143[\mathrm{M}+\mathrm{H}]^{+}$.

\subsection{Cruzain inhibition}

Recombinant cruzain was gently provided by Alison Doak and Dr. Brian Shoichet, from the University of California San Francisco. Cruzain activity was measured as previously described [26], by monitoring the cleavage of the fluorogenic substrate Z-Phe-Argaminomethylcoumarin (Z-FR-AMC) in a Synergy 2 fluorimeter (Biotek), from the Center of Flow Cytometry and Fluorimetry at the Biochemistry and Immunology Department (UFMG), using filters of $340 \mathrm{~nm}$ for excitation and $440 \mathrm{~nm}$ for emission. All assays were performed in sodium acetate $0.1 \mathrm{M} \mathrm{pH} 5.5$ and in the presence of $5 \mathrm{mM}$ dithiothreitol (DTT) and $0.01 \%$ Triton X-100, in a final volume of $200 \mu \mathrm{L}$ and on a 96 well plate format. The final concentration of cruzain was $0.5 \mathrm{nM}$, and the substrate concentration was $2.5 \mu \mathrm{M}$ $(\mathrm{Km}=1 \mu \mathrm{M})$. In all assays, enzyme inhibition was measured after a 10 -min pre-incubation of the compounds with enzyme. Compounds were initially screened at $100 \mu \mathrm{M}$, unless they were insoluble at this concentration, in which cases they were tested at $75 \mu \mathrm{M}$ or $50 \mu \mathrm{M}$. If cruzain inhibition higher than $70 \%$ was observed at the original screening, $\mathrm{IC}_{50}$ was determined based on at least seven inhibitor concentrations, always after pre-incubation with cruzain for $10 \mathrm{~min}$. All assays were performed in at least two independent experiments, each one in triplicates, and were followed for $5 \mathrm{~min}$. Activity was calculated based on comparison to a DMSO control. Data was analysed with Prism 5.0 (GraphPad).

\subsection{Parasites}

Epimastigotes of $T$. cruzi (Y strain) were maintained at $26{ }^{\circ} \mathrm{C}$ in LIT medium (Liver Infusion Tryptose) supplemented with $10 \%$ foetal bovine serum (FBS) (Cultilab, Campinas, SP, Brazil), 1\% hemin (Sigma Co, St. Louis, MO, USA), 1\% R9 medium (Sigma Co), and $50 \mu \mathrm{g} / \mathrm{mL}$ gentamycin (Novafarma, Anápolis, GO, Brazil). Bloodstream trypomastigotes forms of $T$. cruzi were obtained from supernatants of LLC-MK 2 cells previously infected and maintained in RPMI-1640 medium (Sigma Co) supplemented with 10\% FBS, and $50 \mu \mathrm{g} / \mathrm{mL}$ gentamycin at $37{ }^{\circ} \mathrm{C}$ and $5 \% \mathrm{CO}_{2}$.

\subsection{Cytotoxicity for HepG2}

The HepG2 cytotoxicity assay was adapted from Ballell et al. [27]. Actively growing HepG2 cells were removed from a T-175 TC flask using supplemented Eagle's MEM and plated at a density of 3000 cells/well into the 384-well clear-bottom plates using a Multidrop instrument. Prior to addition of the cell suspension, the screening compounds $(250 \mathrm{~nL})$ were dispensed into the plates with an Echo 555 instrument. Plates were allowed to incubate at $37^{\circ} \mathrm{C}$ at $80 \%$ relative humidity for $48 \mathrm{~h}$ under $5 \% \mathrm{CO}_{2}$. The signal developer, CellTiter-Glo (Promega) was added to the plates using a Multidrop and the plates were read using a ViewLux instrument (PerkinElmer).

\subsection{Antiproliferative activity for epimastigotes}

Epimastigotes were counted in a hemocytometer and then dispensed into 96-well plates at a cell density of $10^{6}$ cells/well. Test inhibitors, dissolved in DMSO, were diluted into five different concentrations $(1.23,3.70,11.11,33.33$, and $100 \mu \mathrm{g} / \mathrm{mL})$ and added to the respective wells in triplicate. The plate was incubated for 11 days at $26{ }^{\circ} \mathrm{C}$, and aliquots of each well were collected and the number of viable parasites were counted in a Neubauer chamber, and compared to untreated parasite culture. $\mathrm{IC}_{50}$ values were calculated using non-linear regression on Prism 4.0 GraphPad software. This experiment was done in duplicate, and Benznidazole (LAFEPE, Brazil) were used as the reference inhibitors. 


\subsection{Toxicity for $Y$ strain trypomastigotes}

Trypomastigotes collected from the supernatant of LLC-MK cells were dispensed into 96-well plates at a cell density of $4 \times 10^{5}$ cells/well. Test inhibitors, dissolved in DMSO, were diluted into five different concentrations and added into their respective wells, and the plate was incubated for $24 \mathrm{~h}$ at $37{ }^{\circ} \mathrm{C}$ and $5 \%$ of $\mathrm{CO}_{2}$. Aliquots of each well were collected and the number of viable parasites, based on parasite motility, was assessed in a Neubauer chamber. The percentage of inhibition was calculated in relation to untreated cultures. $\mathrm{IC}_{50}$ calculation was also carried out using nonlinear regression with Prism 4.0 GraphPad software. Benznidazole was used as the reference drug.

\subsection{Docking studies}

The structures of all compounds were obtained by application of the RM1 [34] method, available as part of the SPARTAN 08' program [35], using internal default settings for convergence criteria. Docking calculations and analysis was carried using the T. cruzi cruzain (PDB ID code: 3IUT) as the target [30], in which there was a cocrystallized complex with an inhibitor (referred to as "KB2"). The active site was defined as all atoms within a radius of $6.0 \AA$ from this cocrystallized ligand. The residues GLN19, CYS25, SER61, LEU67, MET68, ASN70, ASP161, HIS162, TRP184 and GLU208 were treated as flexible. The GOLD 5.1 program [36] was used for docking calculations, followed by Binana program [37], which was used to analyse the molecular interactions present in the best docking solutions, using default setting, except for hydrogen bond distance (changed to a maximum of $3.5 \AA$ ). Figures were generated with Pymol [38].

\section{Acknowledgements}

We would like to thank the Brazilian National Research Council (CNPq), Research Foundation of Pernambuco State (FACEPE) and FIOCRUZ for financial support. M.V.O.C. holds a FACEPE scholarship, while D.R.M.M. holds a FAPESB scholarship. We also thank the Department of Fundamental Chemistry-UFPE for recording the ${ }^{1} \mathrm{H}$ NMR, ${ }^{13}$ C NMR, LCMS and IR spectra of all compounds. M.V.O.C. is thankful to P.V.B. in accept a doctoral internship at the University of Queensland. R.S.F. is thankful to Dr. Anna Tochowicz (University of California, San Francisco (UCSF), USA) for providing recombinant cruzain. We also thank members of the Kineto DPU at GlaxoSmithKline Spain for their support in cytotoxicity studies and comments on the manuscript. All authors declare no competing financial interest.

\section{Appendix A. Supplementary data}

Supplementary data related to this article can be found at http:// dx.doi.org/10.1016/j.ejmech.2014.08.012.

\section{References}

[1] $\mathrm{WHO}$ Chagas disease (American trypanosomiasis).

[2] F. Guhl, J.A. Urbina, Specific chemotherapy of Chagas disease: relevance, current limitations and new approaches, Acta Trop. 115 (2010) 55-68.

[3] V.G. Duschak, A.S. Couto, An insight on targets and patented drugs for chemotherapy of Chagas disease, Recent Pat. Antiinfect. Drug Discov. 2 (2007) 19-51.

[4] J.H. McKerrow, P.J. Rosenthal, R. Swenerton, P. Doyle, Development of protease inhibitors for protozoan infections, Curr. Opin. Infect. Dis. 21 (2008) 668-672.

[5] J.A. Urbina, R. Docampo, Specific chemotherapy of Chagas disease: controversies and advances, Trends Parasitol. 19 (2003) 495-501.

[6] J. Urbina, Chemotherapy of Chagas disease, Curr. Pharm. Des. 8 (2002) 287-295.
[7] P. Veiga-Santos, E.S. Barrias, J.F.C. Santos, T.L. de Barros Moreira, T.M.U. de Carvalho, J.A. Urbina, et al., Effects of amiodarone and posaconazole on the growth and ultrastructure of Trypanosoma cruzi, Int. J. Antimicrob. Agents 40 (2012) 61-71.

[8] J.A. Pérez-Molina, J. Sojo-Dorado, F. Norman, B. Monge-Maillo, M. DíazMenéndez, P. Albajar-Viñas, et al., Nifurtimox therapy for Chagas disease does not cause hypersensitivity reactions in patients with such previous adverse reactions during benznidazole treatment, Acta Trop. 127 (2013) $101-104$.

[9] J. McKerrow, Cysteine protease inhibitors as chemotherapy for parasitic infections, Bioorg. Med. Chem. 7 (1999) 639-644.

[10] A.E. Eakin, M.E. McGrath, J.H. McKerrow, R.J. Fletterick, C.S. Craik, Production of crystallizable cruzain, the major cysteine protease from Trypanosoma cruzi, J. Biol. Chem. 268 (1993) 6115-6118.

[11] J.H. McKerrow, M.E. McGrath, J.C. Engel, The cysteine protease of Trypanosoma cruzi as a model for antiparasite drug design, Parasitol. Today 11 (1995) 279-282.

[12] M.E. McGrath, A.E. Eakin, J.C. Engel, J.H. McKerrow, C.S. Craik, R.J. Fletterick, The crystal structure of cruzain: a therapeutic target for Chagas' disease, J. Mol. Biol. 247 (1995) 251-259.

[13] G. Harth, N. Andrews, A.A. Mills, J.C. Engel, R. Smith, J.H. McKerrow, Peptidefluoromethyl ketones arrest intracellular replication and intercellular transmission of Trypanosoma cruzi, Mol. Biochem. Parasitol. 58 (1993) 17-24.

[14] S.S. Gawande, S.C. Warangkar, B.P. Bandgar, C.N. Khobragade, Synthesis of new heterocyclic hybrids based on pyrazole and thiazolidinone scaffolds as potent inhibitors of tyrosinase, Bioorg. Med. Chem. 21 (2013) $2772-2777$.

[15] G.N. Masoud, A.M. Youssef, M.M. Abdel Khalek, A.E. Abdel Wahab I.M. Labouta, A.A.B. Hazzaa, Design, synthesis, and biological evaluation of new 4-thiazolidinone derivatives substituted with benzimidazole ring as potential chemotherapeutic agents, Med. Chem. Res. 22 (2012) $707-725$.

[16] D.R.M. Moreira, S.P.M. Costa, M.Z. Hernandes, M.M. Rabello, G.B. de Oliveira Filho, C.M.L. de Melo, et al., Structural investigation of anti-Trypanosoma cruzi 2-iminothiazolidin-4-ones allows the identification of agents with efficacy in infected mice, J. Med. Chem. 55 (2012) 10918-10936.

[17] C. Pizzo, C. Saiz, A. Talevi, L. Gavernet, P. Palestro, C. Bellera, et al., Synthesis of 2-hydrazolyl-4-thiazolidinones based on multicomponent reactions and biological evaluation against Trypanosoma Cruzi, Chem. Biol. Drug Des. 77 (2011) $166-172$.

[18] D.C. Greenbaum, Z. Mackey, E. Hansell, P. Doyle, J. Gut, C.R. Caffrey, et al. Synthesis and structure-activity relationships of parasiticidal thiosemicarbazone cysteine protease inhibitors against Plasmodium falciparum, Trypanosoma brucei, and Trypanosoma cruzi, J. Med. Chem. 47 (2004) 3212-3219.

[19] M.E. Caputto, A. Ciccarelli, F. Frank, A.G. Moglioni, G.Y. Moltrasio, D. Vega, et al., Synthesis and biological evaluation of some novel 1-indanone thiazolylhydrazone derivatives as anti-Trypanosoma cruzi agents, Eur. J. Med. Chem. 55 (2012) 155-163.

[20] M.Z. Hernandes, M.M. Rabello, A.C.L. Leite, M.V.O. Cardoso, D.R.M. Moreira D.J. Brondani, et al., Studies toward the structural optimization of novel thiazolylhydrazone-based potent antitrypanosomal agents, Bioorg. Med. Chem. 18 (2010) 7826-7835.

[21] A.C.L. Leite, R.S. de Lima, D.R.D.M. Moreira, M.V.D.O. Cardoso, A.C. Gouveia de Brito, L.M. Farias Dos Santos, et al., Synthesis, docking, and in vitro activity of thiosemicarbazones, aminoacyl-thiosemicarbazides and acyl-thiazolidones against Trypanosoma cruzi, Bioorg. Med. Chem. 14 (2006) 3749-3757.

[22] A.C.L. Leite, D.R. de M. Moreira, M.V. de O. Cardoso, M.Z. Hernandes, V.R. Alves Pereira, R.O. Silva, et al., Synthesis, cruzain docking, and in vitro studies of aryl-4-oxothiazolylhydrazones against Trypanosoma cruzi, ChemMedChem 2 (2007) 1339-1345.

[23] D.-N. Zhang, J.-T. Li, Y.-L. Song, H.-M. Liu, H.-Y. Li, Efficient one-pot threecomponent synthesis of $\mathrm{N}$-(4-arylthiazol-2-yl) hydrazones in water under ultrasound irradiation, Ultrason. Sonochem. 19 (2012) 475-478.

[24] F. Chimenti, B. Bizzarri, E. Maccioni, D. Secci, A. Bolasco, P. Chimenti, et al., A novel histone acetyltransferase inhibitor modulating Gcn5 network: cyclopentylidene-[4-(4'-chlorophenyl)thiazol-2-yl)hydrazone, J. Med. Chem. 52 (2009) 530-536.

[25] D.R. Richardson, D.S. Kalinowski, V. Richardson, P.C. Sharpe, D.B. Lovejoy M. Islam, et al., 2-Acetylpyridine thiosemicarbazones are potent iron chelators and antiproliferative agents: redox activity, iron complexation and characterization of their antitumor activity, J. Med. Chem. 52 (2009) 1459-1470.

[26] R.S. Ferreira, C. Bryant, K.K.H. Ang, J.H. McKerrow, B.K. Shoichet, A.R. Renslo, Divergent modes of enzyme inhibition in a homologous structure-activity series, J. Med. Chem. 52 (2009) 5005-5008.

[27] L. Ballell, R.H. Bates, R.J. Young, D. Alvarez-Gomez, E. Alvarez-Ruiz, V. Barroso et al., Fueling open-source drug discovery: 177 small-molecule leads against tuberculosis, ChemMedChem 8 (2013) 313-321.

[28] V. Mersch-Sundermann, S. Knasmüller, X.-J. Wu, F. Darroudi, F. Kassie, Use of a human-derived liver cell line for the detection of cytoprotective, antigenotoxic and cogenotoxic agents, Toxicology 198 (2004) 329-340.

[29] O. Korb, T. Stützle, T.E. Exner, Empirical scoring functions for advanced protein-ligand docking with PLANTS, J. Chem. Inf. Model. 49 (2009) 84-96. 
[30] K. Brak, I.D. Kerr, K.T. Barrett, N. Fuchi, M. Debnath, K. Ang, et al., Nonpeptidic tetrafluorophenoxymethyl ketone cruzain inhibitors as promising new leads for Chagas disease chemotherapy, J. Med. Chem. 53 (2010) 1763-1773.

[31] G.M. Sheldrick, A short history of SHELX, Acta Crystallogr. A 64 (2008) $112-122$

[32] L.J. Farrugia, ORTEP -3 for windows - a version of ORTEP-III with a graphical user interface (GUI), J. Appl. Crystallogr. 30 (1997), 565-565.

[33] L.J. Farrugia, WinGX suite for small-molecule single-crystal crystallography, J. Appl. Crystallogr. 32 (1999) 837-838.
[34] G.B. Rocha, R.O. Freire, A.M. Simas, J.J.P. Stewart, RM1: a reparameterization of AM1 for H, C, N, O, P, S, F, Cl, Br, and I, J. Comput. Chem. 27 (2006) 1101-1111.

[35] Spartan "08 Tutorial and User"s Guide: Wavefunction, 2008.

[36] Gold software.

[37] J.D. Durrant, J.A. McCammon, BINANA: a novel algorithm for ligand-binding characterization, J. Mol. Graph. Model. 29 (2011) 888-893.

[38] The PyMOL Molecular Graphics System, Version 1.3, Schrödinger, LLC, 2002. 